\title{
The Deep-Sea Genus Coronarctus (Tardigrada, Arthrotardigrada) in Brazil, South-Western Atlantic Ocean, with the Description of Three New Species
}

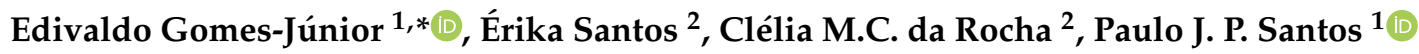 \\ and Paulo Fontoura ${ }^{3,4}$ \\ 1 Bioscience Centre, Department of Animal Biology, Federal University of Pernambuco, Av Prof. Moraes Rego, \\ 1275, Cid. Universitária, Recife PE 50670-901, Brasil; pjp.santos@gmail.com \\ 2 Departamento de Biologia, Universidade Federal Rural de Pernambuco, Av. Manoel de Medeiros, S/N, Dois \\ Irmãos, Recife PE 52171-090, Brasil; erika.bio@gmail.com (É.S.); cavalcanticlelia@yahoo.com.br (C.M.C.d.R.) \\ 3 Department of Biology, Faculty of Sciences, University of Porto. Rua Campo Alegre, \\ 4169-007 Porto, Portugal; pfontoura@fc.up.pt \\ 4 MARE, Marine and Environmental Sciences Centre, ISPA-Instituto Universitário, Rua Jardim do Tabaco, 34 \\ 1149-041 Lisbon, Portugal \\ * Correspondence: edivaldoljr@hotmail.com
}

Received: 30 December 2019; Accepted: 2 February 2020; Published: 5 February 2020

\begin{abstract}
Three new marine tardigrade species from the deep-sea genus Coronarctus are described from the South-Western Atlantic Ocean: Coronarctus dissimilis sp. nov., C. neptunus sp. nov., and C. yurupari sp. nov. These, and C. laubieri Renaud-Mornant, 1987, are the first records of deep-sea tardigrades from this marine region. Specimens of those species were collected from two localities of the Brazilian continental slope (Potiguar and Campos basins) at depths comprised between 150 and $3000 \mathrm{~m}$. Specimens of the three new species have short cephalic appendages and heteromorphic claws, belonging to the, here designated, $C$. tenellus group of species. Each of the new species can be distinguished from all the other species of the group by their peculiar-shaped secondary clavae and claws. The most relevant morphological characters used for the taxonomy of the genus: shape of cephalic cirri, shape of secondary-clavae, size and number of accessory spines on claws, and shape of seminal receptacles, are discussed and an identification key to all ten known Coronarctus species is provided.
\end{abstract}

Keywords: Abyssal; continental slope; Coronarctus dissimilis sp. nov.; C. neptunus sp. nov.; C. yurupari sp. nov.; identification key; meiofauna; taxonomy

\section{Introduction}

Tardigrades (phylum Tardigrada) are micrometazoans that occur worldwide in terrestrial, freshwater, and marine environments. Marine tardigrades are present in all oceans, ranging from the intertidal zone to abyssal depths, inhabiting a great diversity of sediments from fine mud to coarse sand, rocks, algae, and some benthic fauna [1-3].

About 220 species and subspecies of Arthrotardigrada, the order that includes almost all the marine tardigrades, had been described until now [4-6]. However, Bartels et al. [7] estimated that this number would likely exceed 1000, which demonstrates the paucity of knowledge about the biology of marine tardigrades. This problem is particularly severe in the Southern hemisphere, namely in poorly surveyed, deep sublittoral, and abyssal zones [4].

Since the first report of abyssal tardigrades by Thiel [8], from 2600 to $4690 \mathrm{~m}$ deep in the Indian Ocean, only 21 tardigrade species were recorded from the deep-sea (> $200 \mathrm{~m}$ depth, including bathyal 
and abyssal zones) [4,9-11]. From these, only three species were recorded from abyssal depths in the Eastern coast (Angola and Namibia) of the South Atlantic Ocean, Angursa abyssalis Renaud-Mornant, 1981, A. lanceolata Renaud-Mornant, 1981, and Coronarctus tenellus Renaud-Mornant, 1974 [11,12]. So far, studies on Tardigrada in abyssal depths have not been performed for the Southwestern Atlantic Ocean, where 32 tardigrade species have been recorded from shallow intertidal and shallow sublittoral zones [13-15]. Another species, Ligiarctus alatus Gomes-Jr. et al., 2018, collected from depths of 100 to $150 \mathrm{~m}$, is the deepest tardigrade record in this region [16].

For nature management purposes, the need for meiofauna species inventories is especially justified in order to evaluate the environmental effects of human activities [17-19], for example oil extraction, which the Brazilian coast is strongly subjected to. Thus, in the frame of a project aiming to assess the impact of this activity on natural resources and marine communities, specimens of the deep-sea tardigrade genus Coronarctus Renaud-Mornant, 1974 were recorded from two localities in the major oil extraction basins in Brazil (Campos and Potiguar basins).

After the description of $C$. tenellus, the type species of the genus, recorded from abyssal sediments (1600-4700 m deep) in several localities of the Somalian coast in the Indian Ocean, six other species were assigned to this genus. Although, still remaining restricted, the geographic distribution of the species of the genus Coronarctus was extended to the Canal de Mozambique in the Indian Ocean [20]; the Namibian coast in the South-Eastern Atlantic Ocean as referred above [12]; France, Faroe Bank, and Spain in the North-Eastern Atlantic Ocean [20-23]; U.S.A. and the Gulf of Mexico [20,24] in the North-Western Atlantic, and Japan in the Pacific Ocean [25].

In this study, we provide the description of three new species to science: Coronarctus dissimilis sp. nov., C. neptunus sp. nov., and C. yurupari sp. nov., and a new record, C. laubieri Renaud-Mornant, 1987, from the Brazilian coast, South-Western Atlantic Ocean. Additionally, based mainly on new types of secondary clavae and claws observed in the new species, a dichotomous key to the identification of all Coronarctus species is also provided.

\section{Materials and Methods}

Tardigrades were collected from deep-sea sediments obtained from two localities of the Brazilian continental slope (South-Western Atlantic Ocean), at the interference zone of two relevant oil extraction basins: Campos Basin ( $\left.21^{\circ} 55^{\prime}-23^{\circ} 56^{\prime} \mathrm{S} ; 39^{\circ} 55^{\prime}-45^{\circ} 55^{\prime} \mathrm{W}\right)$, Rio de Janeiro State, at 150-3000 $\mathrm{m}$ in depth, and Potiguar Basin $\left(4^{\circ} 36^{\prime}-4^{\circ} 46^{\prime} \mathrm{S} ; 36^{\circ} 05^{\prime}-36^{\circ} 31^{\prime} \mathrm{W}\right)$, Rio Grande do Norte State, at 900-2500 $\mathrm{m}$ in depth (Figure 1). Both sites are characterized by the presence of submarine canyons and the sediments are predominantly constituted of fine muds. Samples were obtained in 2009, via a box corer $(50 \times 50 \mathrm{~cm})$, during the oceanographic campaigns (Environmental Characterization Project of the Continental Slope in the Potiguar Basin, and Environmental Characterization Project of the Campos Basin) developed by PETROBRAS (Petróleo Brasileiro SA). Then sediment subsamples were taken with $10 \mathrm{~cm}$ long PVC cores (diameter $3.7 \mathrm{~cm}$ ) and fixed in $4 \%$ buffered formaldehyde.

At the laboratory sediments were washed and sieved using a $30 \mu \mathrm{m}$ mesh sieve. Tardigrades were sorted under a dissecting microscope and transferred to microslides with coverslips. Specimens were permanently mounted in pure glycerin with formalin (ca. 1\%) and sealed with nail paraffin. Animals were examined, measured (all measurements in micrometers- $\mu \mathrm{m}$ ) and microphotographed under 1000x oil immersion, with a Leica DM 2500 Phase Contrast Microscopes (Leica Microsystems, Wetzlar, Germany) and a Zeiss Axioimager 2 Differential Interference Contrast Microscope (ZEISS Microscopy, Jena, Germany), both equipped with digital cameras and imaging software (Leica Application Suite V4.9 and Zen Imaging Software for Leica and Zeiss microscopes respectively). All photomicrographs were made under DIC, and structures were measured only if they were undamaged and if their orientation was suitable. When symmetrical structures were measured, the larger value was recorded when different values were obtained. Identifications were based on Fontoura et al. [2] and on original species descriptions in the literature [20,22,24,26,27]. Tardigrade taxonomy follows Degma and Guidetti [5], 
Fujimoto et al. [28] and Degma et al. [6], morphological terminology follows Fontoura et al. [2], and Møbjerg et al. [29].

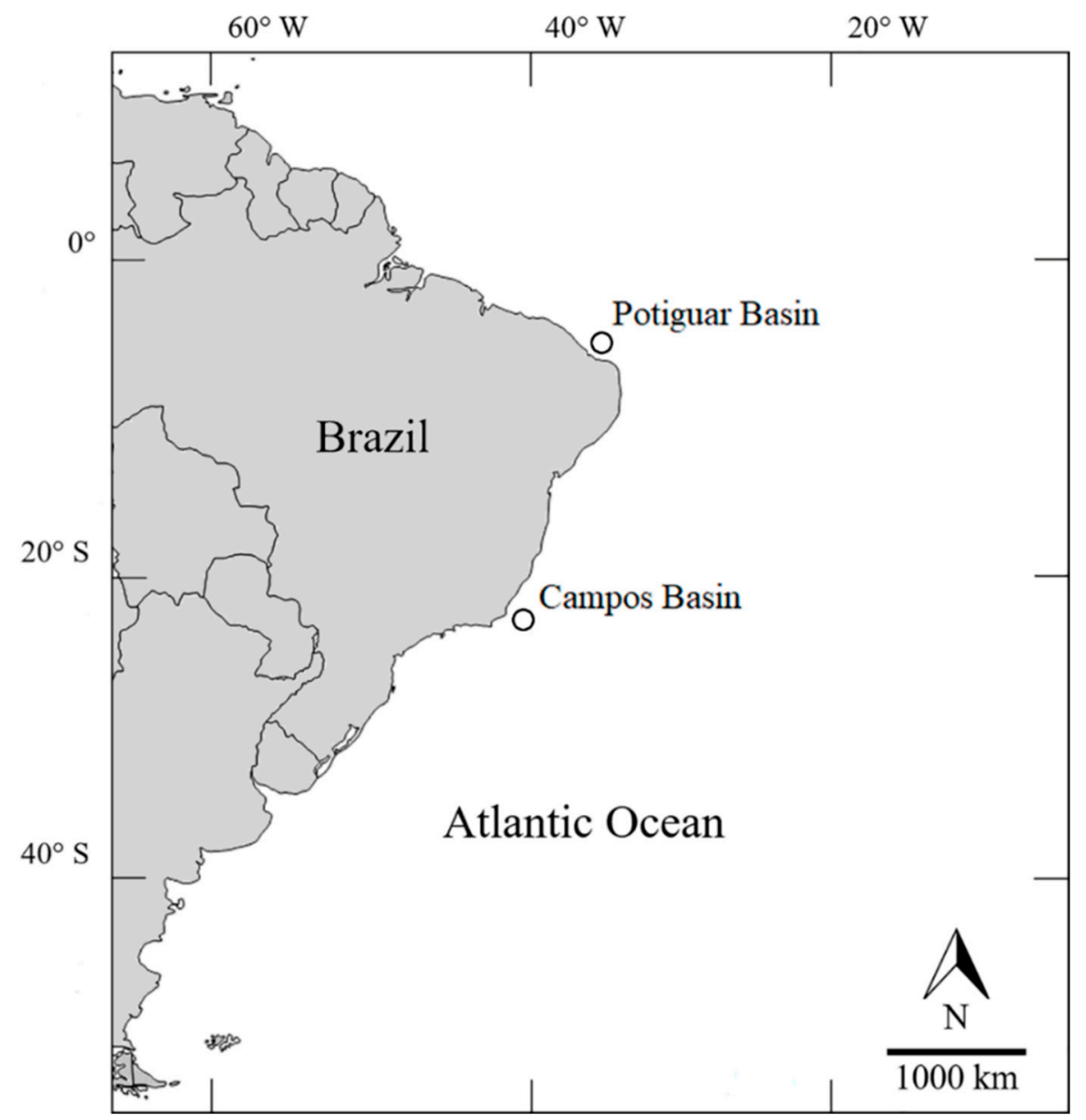

Figure 1. Map of collecting localities (empty circles) in the Potiguar Basin and Campos Basin in the Brazilian continental slope, South-Western Atlantic Ocean.

\section{Results}

A total of 35 tardigrades of the genus Coronarctus, representing four species, were extracted from samples ranging from 150 to $3000 \mathrm{~m}$ in depth. Species recorded were Coronarctus dissimilis sp. nov. (12 specimens), C. laubieri Renaud-Mornant, 1987 (7 specimens), C. neptunus sp. nov. (5 specimens), and C. yurupari sp. nov. (11 specimens). Taxonomic accounts are given for each of these below.

Taxonomic Accounts

Phylum: Tardigrada Doyère 1840

Class: Heterotardigrada Marcus, 1927

Order: Arthrotardigrada Marcus, 1927

Family: Coronarctidae Renaud-Mornant, 1974

Genus: Coronarctus Renaud-Mornant, 1974

3.1. Coronarctus dissimilis $s p$. nov.

Figures 2-4, Supplementary Table S1. 


\subsubsection{Diagnosis}

Coronarctus with reduced leaf-like cephalic appendages. Median cirrus inserted at the rear of the head, near the posterior edges of secondary clavae. Subspherical primary clavae. Flattened secondary clavae with two dorsal lobes and two ventral lobes each. The anterior dorsal lobe located far ahead; the second dorsal lobe located in a medial position. The posterior ventral lobes are closely jointed and separated from the anterior lobes by a deep indentation. Cuticle smooth. Sensory organs present on each pair of legs and additional flexible spine-like processes on legs IV. Heteromorphic claws: claws of legs IV much longer than claws of the first three pairs of legs. External claws slightly shorter than internal claws. All claws with apical accessory spines.

\subsubsection{Type Locality}

Campos Basin, Rio de Janeiro State, Brazil; specimens were collected from the Brazilian continental slope at $1300 \mathrm{~m}$ below sea level, in a submarine canyon, at two sampling points $\left(21^{\circ} 55^{\prime} \mathrm{S}, 39^{\circ} 55^{\prime} \mathrm{W}\right.$ and $21^{\circ} 55^{\prime} \mathrm{S}, 45^{\circ} 55^{\prime} \mathrm{W}$ ). The sediment type is fine mud.

\subsubsection{Type Material and Type Repository}

The holotypic female (slide Tard-UFRPE-01-108), the allotypic male (slide Tard-UFRPE-01-110) and ten paratypes; six females (slides Tard-UFRPE-01-106 - Tard-UFRPE-01-108, Tard-UFRPE-01-110 and C.XI-73); one specimen of unknown gender (slide Tard-UFRPE-01-111), and three two-clawed larvae (slides Tard-UFRPE-01-109 and C.XI-73). The holotype, allotype, and six paratypes are deposited in the Laboratório de Meiofauna, Departamento de Biologia, Universidade Federal Rural de Pernambuco, Brazil (collection of Clélia Rocha). Four paratypes, two females and two larvae (slide C.XI-73), are deposited in the Department of Biology, Faculty of Sciences, University of Porto, Portugal (collection of P. Fontoura).

\subsubsection{Etymology}

From the Latin dissimilis (=dissimilar, unequal) as the two most external claws of the new species are considerably thinner than the two most internal claws on each leg I-III.

\subsubsection{Description of Holotype}

Adult female $350 \mu \mathrm{m}$ long and $86.1 \mu \mathrm{m}$ wide (Figures 2A and 3A). The body, cylindrical and elongated, is covered by a smooth and transparent cuticle with metameric folds. Coelomocytes and other globular bodies (about $5 \mu \mathrm{m}$ in diameter) are present in the body cavity. The head, narrower than the body, is made of two parts bearing short leaf-like cephalic cirri: the first conical part bears the paired internal ( $4.4 \mu \mathrm{m}$ long) and external cirri $(7.3 \mu \mathrm{m}$ long), and the unpaired median cirrus $(2.6 \mu \mathrm{m})$; the posterior second part bears the subspherical primary clavae and the leaf-like lateral cirri $A$ (Figures $2 \mathrm{~B}, \mathrm{C}$ and $3 \mathrm{~B})$. Primary clavae $(6.2 \mu \mathrm{m}$ in diameter) are embedded into a socket and separated from the short lateral cirri $A(5.2 \mu \mathrm{m})$ (Figure 3B).

The flattened secondary clavae have two dorsal lobes and two ventral lobes each. The anterior dorsal lobe is located far ahead and can be easily overlooked; the posterior dorsal lobes are very wide and located in a medial position (Figures $2 \mathrm{~B}$ and $3 \mathrm{C}$ ). The posterior lobes are closely jointed. After the insertion of the external cephalic cirri, the anterior ventral lobes display a small projection that when deformed by the slide mounting process can be easily confused with a third ventral lobe (see Figure 2C). The anterior ventral lobes are separated from the posterior lobes by a deep indentation (Figures 2C and 3D). The posterior ventral lobes of secondary clavae are closely jointed. The median cirrus is inserted in the rear of the head, after the posterior dorsal lobes and near the posterior edges of the secondary clavae (Figures $2 \mathrm{~B}$ and $3 \mathrm{C}$ ). 


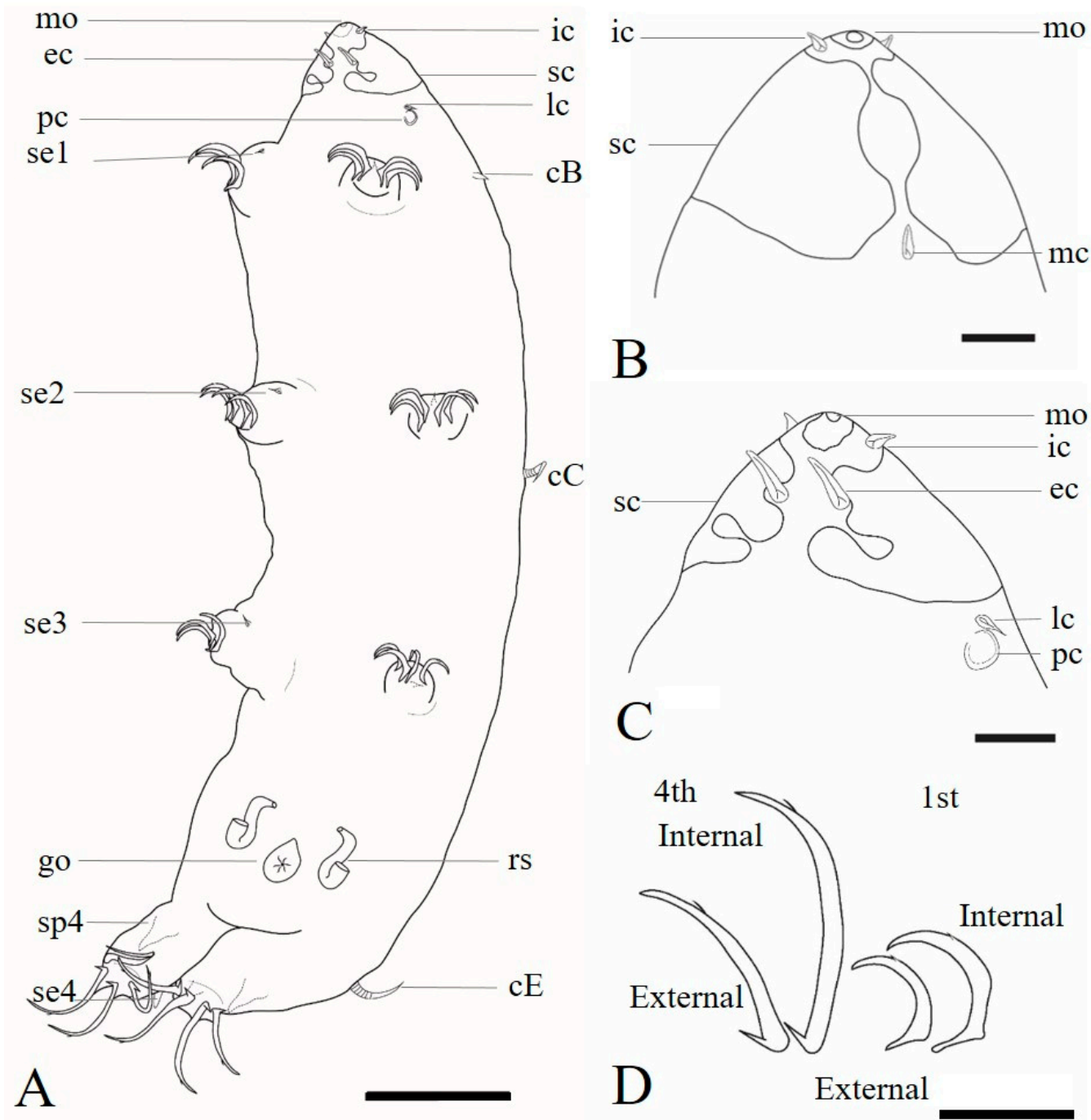

Figure 2. Coronarctus dissimilis sp. nov. Drawings based on the holotype. (A) Ventral view of the body; (B) Dorsal view of the head; (C) Ventral view of the head; (D) Claws of the first and fourth pairs of legs. Abbreviations: $\mathrm{CB}$-cirrus $B, \mathrm{cC}$-cirrus $C$; $\mathrm{CE}$-cirrus E; ec-external cirrus; go-gonopore; ic-internal cirrus; lc-lateral cirrus $A$; mc - median cirrus; mo-mouth; pc—primary clava; rs—seminal receptacle; sc—secondary clava; se1-4—sensory organ legs I-IV; sp4—coxal process on leg IV. Scale bars: A-50 $\mu \mathrm{m}$, B-D-10 $\mu \mathrm{m}$.

Trunk cirri $B(5.1 \mu \mathrm{m}$ long), $C(23.6 \mu \mathrm{m}$ long), and $E(20.6 \mu \mathrm{m}$ long) are present as typical of the genus. Each trunk cirrus consists of a very short cirrophore, accordion-like scapus and tubular flagellum which is very short on cirrus $B$, tapering into a blunt tip.

The legs are short and stout. Legs IV are longer than the first three leg pairs. Sensory organs are present on all legs, very short on legs I-III $(2.2,3.4$, and $5.3 \mu \mathrm{m}$ long, respectively) and longer on legs IV $(6.7 \mu \mathrm{m}$ long). Sensory organs consist of a needle-like structure partly embedded into a conical base. On legs IV the needle-like structure is shorter, ending in a blunt apex (Figure 4A). A flexible spine-like process (10.7 $\mu \mathrm{m}$ long) is inserted dorsally in the coxa of legs IV, above the sensory organ (Figure $4 \mathrm{~A}$ ).

The claws, supplied with basal spurs and connected by a membrane, display heteromorphy: claws on the legs IV (external claws 27.4 and 31.2; internal claws 37.1 and $35.7 \mu \mathrm{m}$ long) are much longer than claws on the first three leg pairs (on legs I: external claws 19.4 and 18.6; internal claws 24.4 and $24.5 \mu \mathrm{m}$ long) (Figures 2A,D and 3A). On all legs, external claws are slightly shorter than internal claws (see Table S1 for measurements). Claws on legs I are more robust than claws on legs II and III. On the first three leg pairs and particularly on legs I, the two most external claws are considerably 
thinner than the two most internal claws (Figures 3B and 4B). All claws with apical short accessory spines (Figures 2D and 4D).

The mouth opening is terminal and surrounded by cuticular folds. Details of the buccal apparatus were not observed.

The ovary is odd and dorsal. Two pear-shaped seminal receptacles, with ducts directed frontwards, are present next to the rosette-like gonopore (Figure 4E). The distance between gonopore and anus, a fissure surrounded by a wrinkled cuticle, is $15.7 \mu \mathrm{m}$.

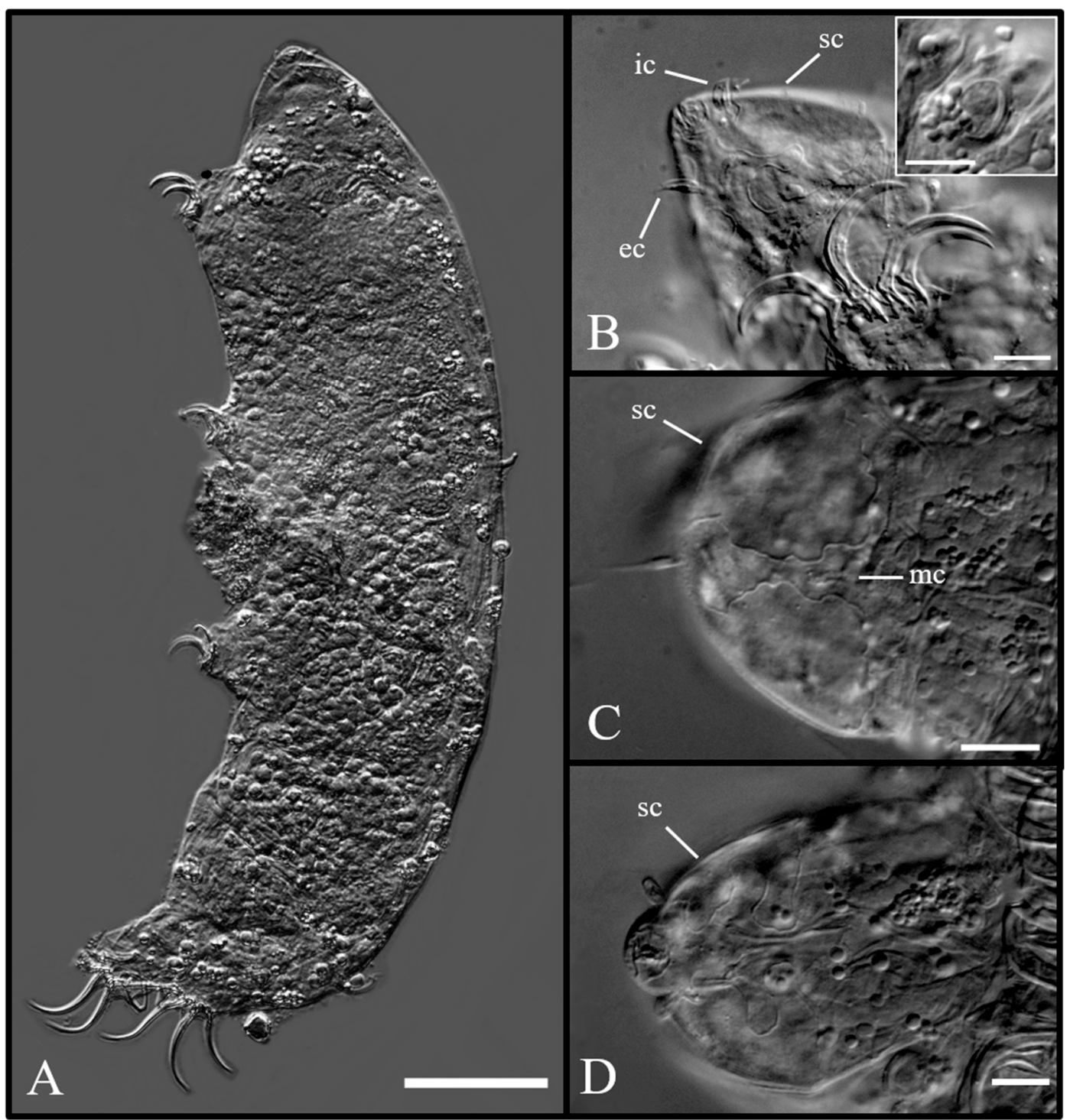

Figure 3. Coronarctus dissimilis sp. nov. (A) Habitus; (B) Ventral view of the head showing the cephalic cirri, secondary clavae, and claws on legs I. Insert with detail of the primary clava embedded into socket; (C) Posterior dorsal lobes of secondary clavae and median cirrus; (D) Ventral lobes of secondary clavae. Abbreviations: ec-external cirrus; ic—internal cirrus; mc-median cirrus; sc—secondary clava. Scale bars: $10 \mu \mathrm{m}$.

\subsubsection{Remarks}

The observed male does not display external sexual dimorphism, except for the gonopore that is a slit on the top of a cylindrical cuticular fold. However, this assumption needs to be confirmed, particularly for morphometric data, with the examination of additional material to increase the sample size. 
The two-clawed larvae lack gonopore and anus and the most external claw on legs I are particularly thin (Figure 4F). As in adults, the claws also have short apical accessory spines. In larvae sensory organs were not observed on legs I-III probably due to their small size. For the other characters, larvae are similar to adults.

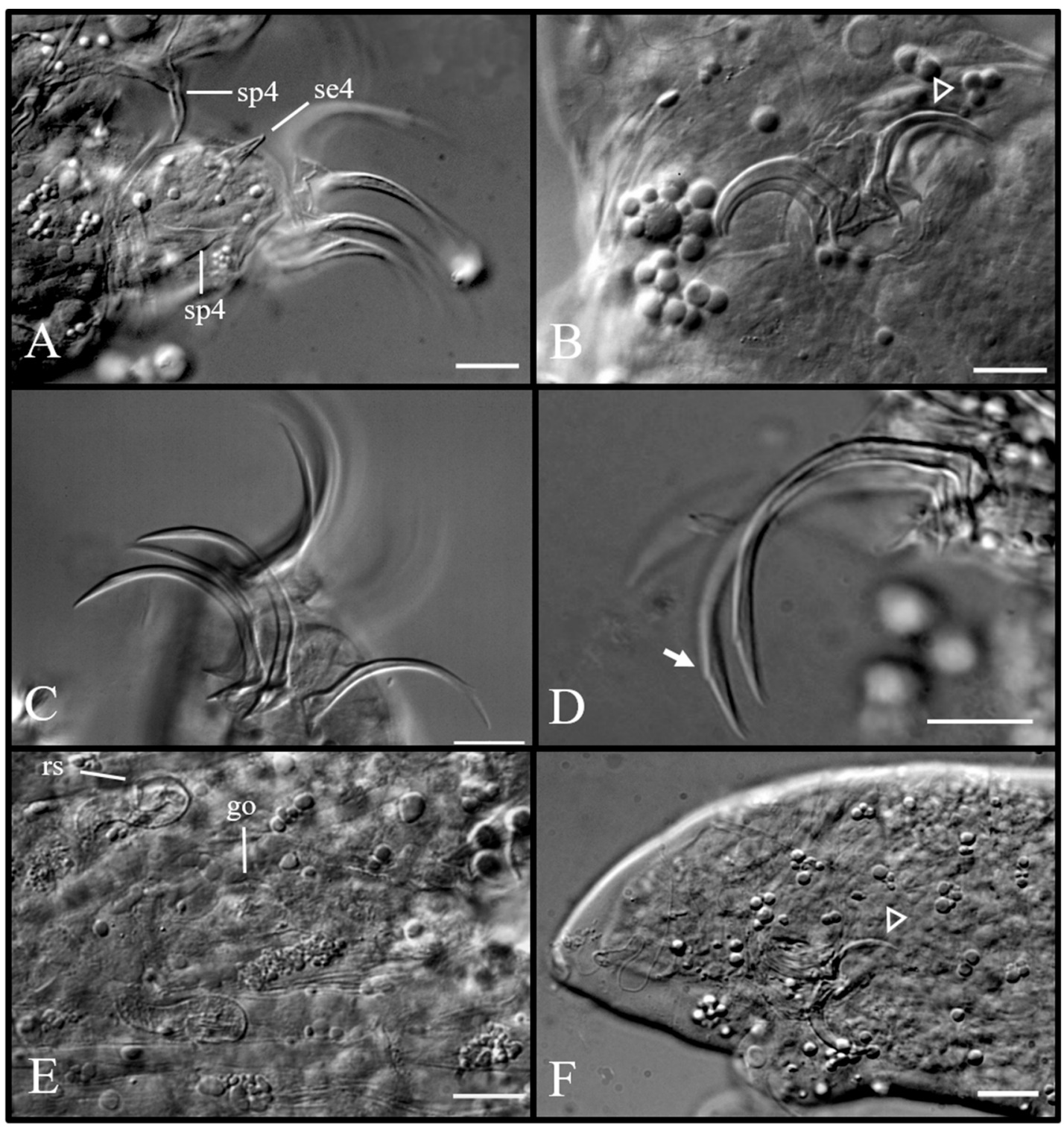

Figure 4. Coronarctus dissimilis sp. nov.; (A) Legs IV, showing the sensory organ and coxal processes; (B) Claws on legs I, notice the thinner most external claws (empty arrowhead); (C) Claws on legs IV; (D) Internal claws on leg IV, showing the accessory spine (arrow): (E) Female gonopore and seminal receptacles; (F) Larva, showing the thinner external claw (empty arrowhead). Abbreviations: go-gonopore; rs-seminal receptacle; se4—sensory organ on legs IV; sp4-coxal process on leg IV. Scale bars: $10 \mu \mathrm{m}$.

\subsubsection{Differential Diagnosis}

Currently, seven species are assigned to the genus Coronarctus. Based on the relative size of claws and length of cephalic appendages, which are considered as reliable taxonomic characters $[20,22,24]$, two main groups can be recognized. Four species, exhibit claw heteromorphy (i.e., claws on legs IV much longer than claws of legs I-III) and have short cephalic appendages ( $<10 \mu \mathrm{m}$ long): C. tenellus, C. disparilis Renaud-Mornant, 1987, C. laubieri and C. mexicus Romano III, Gallo, D'Addabbo, Accogli, 
Baguley and Montagna, 2011. Three other species, C. stylisetus Renaud-Mornant, 1987, C. fastigatus Renaud-Mornant, 1987 and C. verrucatus Hansen, 2007, display claw homomorphy (claws on all legs similar in length) and long $(>10 \mu \mathrm{m})$ cephalic appendages. From now on these two groups will be designated as $C$. tenellus group of species and $C$. stylisetus group of species, respectively, referring to the two first described species within each group.

Coronarctus dissimilis sp. nov., in having short leaf-like cephalic appendages and claws displaying heteromorphy, belongs to the $C$. tenellus group. Within this group, only one described species, C. laubieri, also has the median cirrus inserted at the rear of the conical part of the head and secondary clavae with the posterior ventral lobes separated from the anterior ventral lobes by a deep indentation (see Figure 5). The new species can be clearly distinguished from C. laubieri in having differently shaped secondary clavae: in the new species, the posterior dorsal lobes are located at a medial position, before the insertion of the median cirrus, while in C. laubieri they are located at the rear, and the median cirrus is inserted between them (see Figure 5). Additionally, in C. dissimilis sp. nov. external claws on legs IV are just slightly shorter than internal claws (mean values of external claw length/mean values of internal claw length $=0.77-0.82$, assessed in 7 adult specimens with the 4 claws measured) and all claws have well-visible dorsal accessory spines. On the contrary, in C. laubieri external claws are markedly shorter than internal claws (in the holotype external claw length/internal claw length $=0.40$ ) and minute apical accessory spines are present on internal claws only. Moreover, in comparison with C. laubieri, in C. dissimilis sp. nov. the two most external claws on each leg I-III are particularly thin when compared with the two most internal claws.

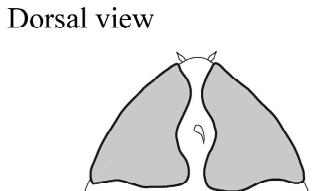

Ventral view

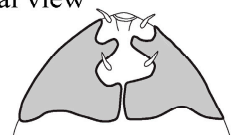

C. disparilis
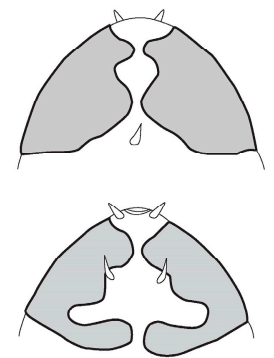

C. dissimilis sp. nov.
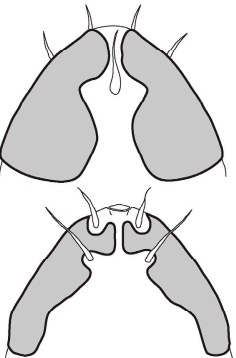

C. fastigatus
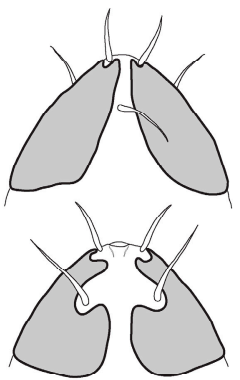

C. stylisetus
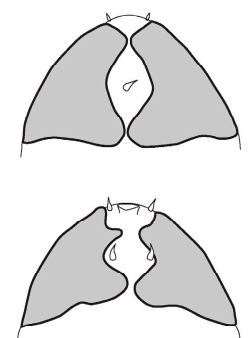

C. tenellus
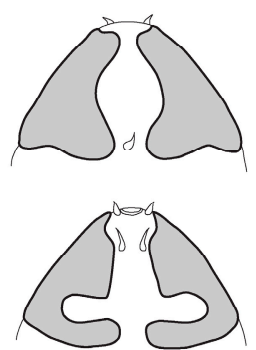

C. laubieri

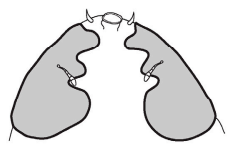

C. mexicus
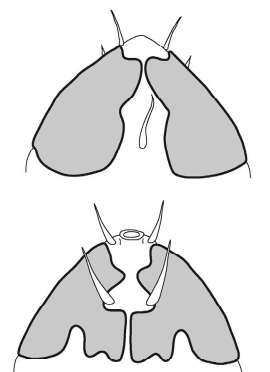

C. verrucatus
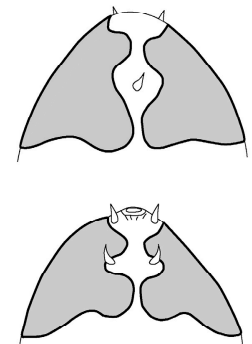

C. yurupari sp. nov.

Figure 5. Drawings of secondary clavae of all Coronarctus species (C. tennellus, redrawn from RenaudMornant [26]; C. disparilis, C. fastigatus, C. laubier,i and C. stylisetus, redrawn from Renaud-Mornant [20]; C. exicus, redrawn from Romano [24], dorsal view not provided, C. verrucatus redrawn from Hansen [22]; C. dissimilis, C. neptunus, and C. yurupari are original drawings).

\subsection{Coronarctus laubieri Renaud-Mornant, 1987}

Supplementary Figures S1 and S2, Supplementary Table S2. 


\subsubsection{Material Examined}

Seven specimens (two females, 244 and $395 \mu \mathrm{m}$ long, one male $259 \mu \mathrm{m}$ long, one specimen of unknown gender $362 \mu \mathrm{m}$ long and a two-clawed larva $256 \mu \mathrm{m}$ long) were collected from the Potiguar Basin $\left(4^{\circ} 36^{\prime}-4^{\circ} 46^{\prime}\right.$ S; $36^{\circ} 05^{\prime}-36^{\circ} 31^{\prime}$ W), Rio Grande do Norte State, Brazil, in the Brazilian continental slope between 1985 and $2500 \mathrm{~m}$ below sea level; and two specimens (female $445 \mu \mathrm{m}$ long and specimen of unknown gender $294 \mu \mathrm{m}$ long) were collected from Campos Basin $\left(22^{\circ} 10^{\prime} \mathrm{S} ; 40^{\circ} 20^{\prime} \mathrm{W}\right)$, Rio de Janeiro State, Brazil, in the Brazilian continental slope between 2500 and $3000 \mathrm{~m}$ below sea level (see Table S2 for measurements and Figures S1 and S2). At both sampling sites the sediment type is fine grain.

\subsubsection{Remarks}

Accessory spines on claws were not observed on the examined specimens. For all the other characters the specimens perfectly match the description of the species in Renaud-Mornant [20]. Up until now, this species was recorded in the North Atlantic only at depths of between 625 and $4190 \mathrm{~m}$ below sea level [4]: five records [20] from St. KG 215, terra typica ( $\left.47^{\circ} 35^{\prime} 65^{\prime \prime} \mathrm{N} ; 9^{\circ} 39^{\prime} 9^{\prime \prime} \mathrm{W}\right)$, one record [30] from France, Bay of Biscay $\left(46^{\circ} 18^{\prime} 68^{\prime \prime} \mathrm{N} ; 12^{\circ} 33^{\prime} 90^{\prime \prime}\right.$ W), and one record [24] from U.S.A., Gulf of Mexico $\left(27^{\circ} 07^{\prime} \mathrm{N} ; 92^{\circ} 20^{\prime} \mathrm{W}\right)$. This is the first record of this species from the South-Western Atlantic Ocean.

\subsection{Coronarctus neptunus sp. nov.}

Figures 6-8, Supplementary Table S3.

\subsubsection{Diagnosis}

Coronarctus with reduced cephalic cirri, each with annulated scapus and flagellum. Spherical primary clavae. Flattened secondary clavae with two ventral lobes, the posterior ones jointed. Dorsally, the internal edges of secondary clavae, diverging posteriorly, are almost rectilinear, not displaying evident lobes. Median cirrus inserted at about equal distance from the mouth opening and the posterior edges of secondary clavae. Cuticle smooth. Sensory organs present on each pair of legs. The leg sensory organ on legs I-III consists of a needle-like structure, protruding from a wrinkled broad cylindrical basal portion, in which it is partly embedded. The wrinkled basal portion is conical on legs IV with the embedded needle-like structure slightly protruding. Similar spine-like processes are present on the coxa of legs IV. Heteromorphic claws (claws of legs IV much longer than claws of the first three pairs of legs) with very robust basal spurs. Internal claws on legs IV with a pair of apical spines; on external claws IV a robust spine is present mediodorsally. Minute accessory spines are present on legs I-III.

\subsubsection{Type Material and Type Repository}

Holotypic female (slide Tard-UFRPE-01-103), allotypic male (slide Tard-UFRPE-01-102), and three paratypes, two females and a specimen of unknown gender (slides Tard-UFRPE-01-101 and Tard-UFRPE-01-104), are deposited in the Laboratório de Meiofauna, Departamento de Biologia, Universidade Federal Rural de Pernambuco, Brazil (collection of Clélia Rocha).

\subsubsection{Type Locality}

Campos Basin, Rio de Janeiro State, Brazil; specimens were collected from the Brazilian continental slope between 150 and $1300 \mathrm{~m}$ below sea level $\left(21^{\circ} 55^{\prime}-23^{\circ} 56^{\prime} \mathrm{S} ; 39^{\circ} 55^{\prime}-40^{\circ} 56^{\prime} \mathrm{W}\right)$. The sediment type is fine mud.

\subsubsection{Etymology}

The epithet is inspired by the trident used by Neptuno, the Roman god of the sea, as an allusion to the long and sharp spines of the claws of the new species. 


\subsubsection{Description of Holotype}

Adult female with an elongated cylindrical body (about $216 \mu \mathrm{m}$ long and $75.8 \mu \mathrm{m}$ wide) with a constriction between each pair of legs (Figures 6A and 7A). Cuticle smooth and transparent.

A full set of short cephalic appendages is inserted into a conical head (Figures 6B,C and 7B,C). Divided lateral cirri $A(11.1 \mu \mathrm{m})$, each consisting of an annulated scapus followed by a smooth flagellum, ending in a spherical tip, are located in the posterior portion of the head and inserted separately but at the same time closely to the spherical and not pedunculated primary clavae $(5.6 \mu \mathrm{m})$ (Figures $6 \mathrm{~B}$ and 7C,D). Short median cephalic cirrus $(4.0 \mu \mathrm{m})$ is inserted at about equal distance from the anterior head margin $(17 \mu \mathrm{m})$ and the posterior edges of secondary clavae $(15 \mu \mathrm{m})$ (Figure $6 \mathrm{C})$. Dorsal internal and ventral external cephalic cirri are short, similar in length (5.5 and $6.1 \mu \mathrm{m}$ long respectively), and inserted anteriorly, close to the mouth opening (Figures 6B and 7B). The cephalic cirri end forming a blunt tip and the division into annulated scapi and flagella, although not confirmed, is likely. The flattened secondary clavae have two ventral lobes, the posterior ones jointed (Figures $6 \mathrm{~B}$ and $7 \mathrm{~B}$ ). Dorsally the internal edges of secondary clavae are almost rectilinear, not displaying evident lobes; left and right edges, which are very closely jointed anteriorly, diverging backwards gradually (Figures 6C and 7C).
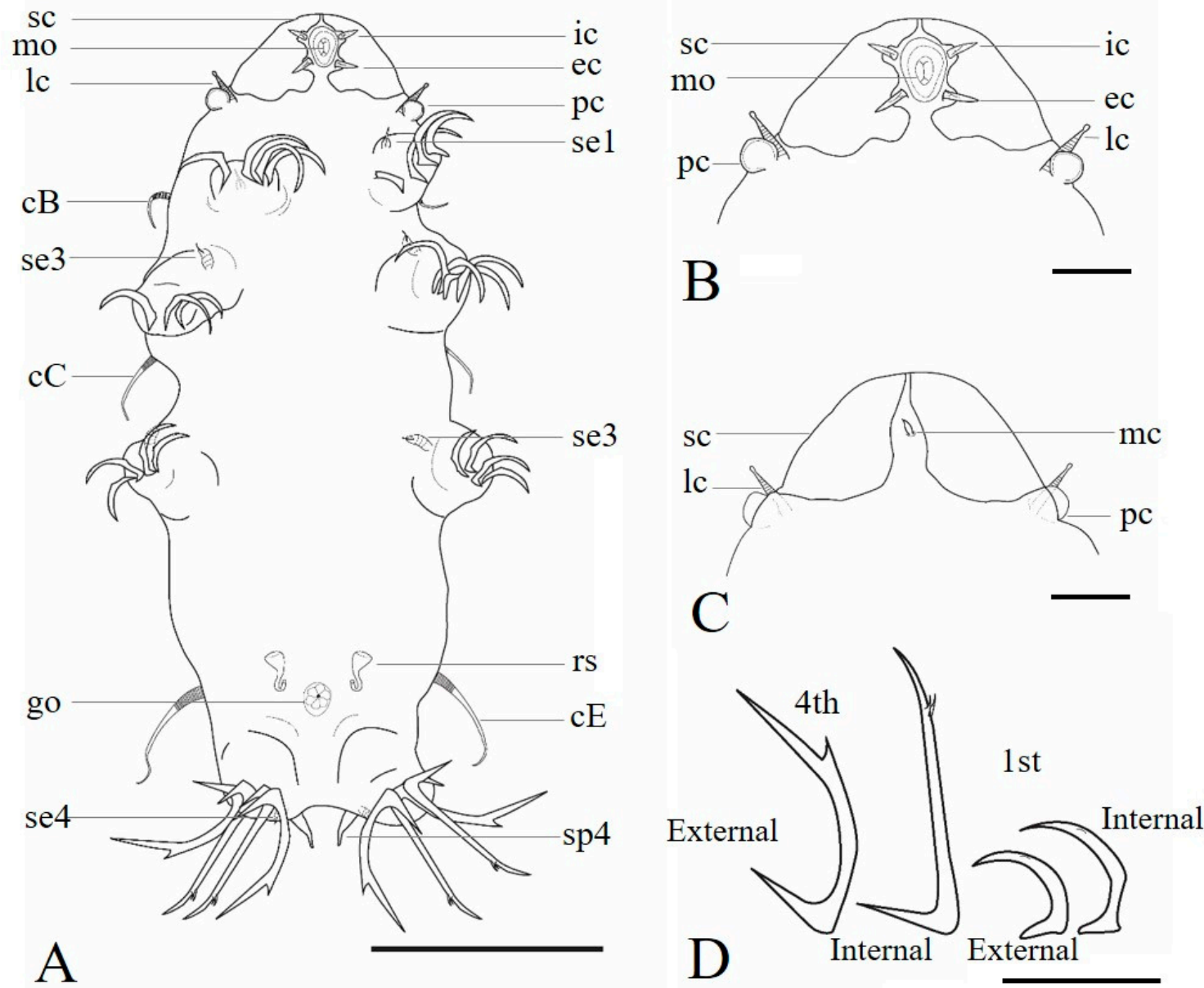

Figure 6. Coronarctus neptunus sp. nov. Drawings based on the holotype. (A) Ventral view of the body; (B) Dorsal view of the head; (C) Ventral view of the head; (D) Claws of the first and fourth pairs of legs. Abbreviations: $\mathrm{cB}$-cirrus $B, \mathrm{cC}$ - cirrus $C$; $\mathrm{cE}$-cirrus $E$; ec-external cirrus; go-gonopore; ic—internal cirrus; lc-lateral cirrus $A$; mc-median cirrus; mo-mouth; pc-primary clava; rs—seminal receptacle; sc—secondary clava; se1-4—sensory organ legs I-IV; sp4—coxal process on leg IV. Scale bars: A-50 $\mu \mathrm{m}$, B-D-10 $\mu \mathrm{m}$. 


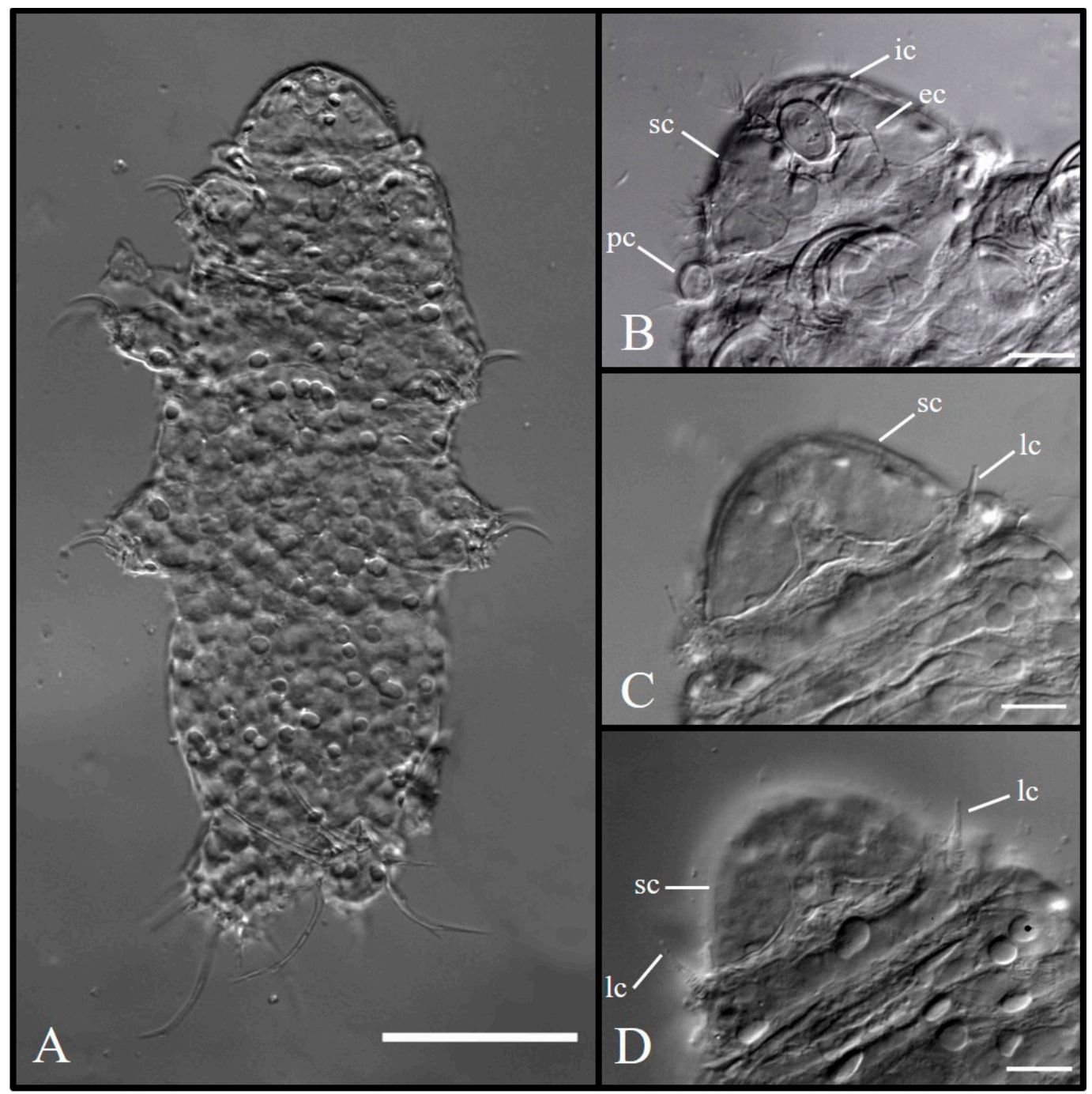

Figure 7. Coronarctus neptunus sp. nov. (A) Habitus; (B) Ventral view of the head showing the cephalic sensory organs. The ventral lobes of secondary clavae are visible; (C) Dorsal view of the head, showing the secondary clavae, primary clavae, and the spherical tip of lateral cirri $A$; (D) Lateral cirri $A$, notice the annulated scapi. Abbreviations: ic - internal cirrus; ec-external cirrus; lc-lateral cirrus A; pc-primary clava; sc—secondary clava. Scale bars: $10 \mu \mathrm{m}$.

Trunk cirri $B(8.0 \mu \mathrm{m}), C(17.1 \mu \mathrm{m})$, and $E(21.7 \mu \mathrm{m})$ each with short cirrophore (almost imperceptible), accordion-like scapus and flagellum.

The legs, particularly the first three pairs, are short and stumpy. The hind legs are slightly longer. Sensory organs present on all pairs of legs. Leg sensory organs on legs I-III (Figure 8A,B) consist in a needle-like structure (about $2.0 \mu \mathrm{m}$ long), partly embedded into a wrinkled broad cylindrical basal portion and partly protruding (basal portion is 4.0, 8.0, and $8.0 \mu \mathrm{m}$ long in legs I, II, and III, respectively). On legs IV sensory organs (not measured in the holotype) are similar but the wrinkled basal portion is more conical and the protruding needle-like structure is relatively smaller. A refractive organ is present at the apex of the basal portion. Similar spine-like processes $(16.0 \mu \mathrm{m}$ long $)$ are present on the coxa of the hind legs (Figure 8D).

Each leg has four claws with robust basal spurs. Claws exhibit marked heteromorphy: on the claws of the fourth pair of legs (external and internal claws are 39.2/39.7 and 43.0/44.5 $\mu \mathrm{m}$, respectively) are much longer than claws on the first three pairs of legs (on legs I external claws are $22.0 \mu \mathrm{m}$, internal claws $27.0 \mu \mathrm{m}$ long); on all legs internal and external claws are similar in size or internal claws are slightly longer than external claws (see Table S3 for measurements, Figures 6A,D, 7A and 8A-C). 
Minute accessory spines were observed on several (but not all) internal and external claws on legs I-III. The small size of accessory spines and the orientation of claws are a probable reason for not having observed accessory spines on all claws. Therefore, the presence of accessory spines on all claws on legs I-III is likely. All claws on legs IV (Figures 6A,D and 8C) are slightly bent and have very long sharp basal spurs (14.0 and 7.0 $\mu \mathrm{m}$ on external and internal claws respectively) and strong and long accessory dorsal spines: a single robust spine, about $4.6 \mu \mathrm{m}$, located far from the claw tip (about $10 \mu \mathrm{m}$, i.e., 1/3 of the claw length) on external claws, and a pair of slightly shorter $(3.4 \mu \mathrm{m})$ but evident spines located in a more apical position (about $6.7 \mu \mathrm{m}$ far from the claw tip) on internal claws (Figures $6 \mathrm{~B}$ and $8 \mathrm{C}$ ).

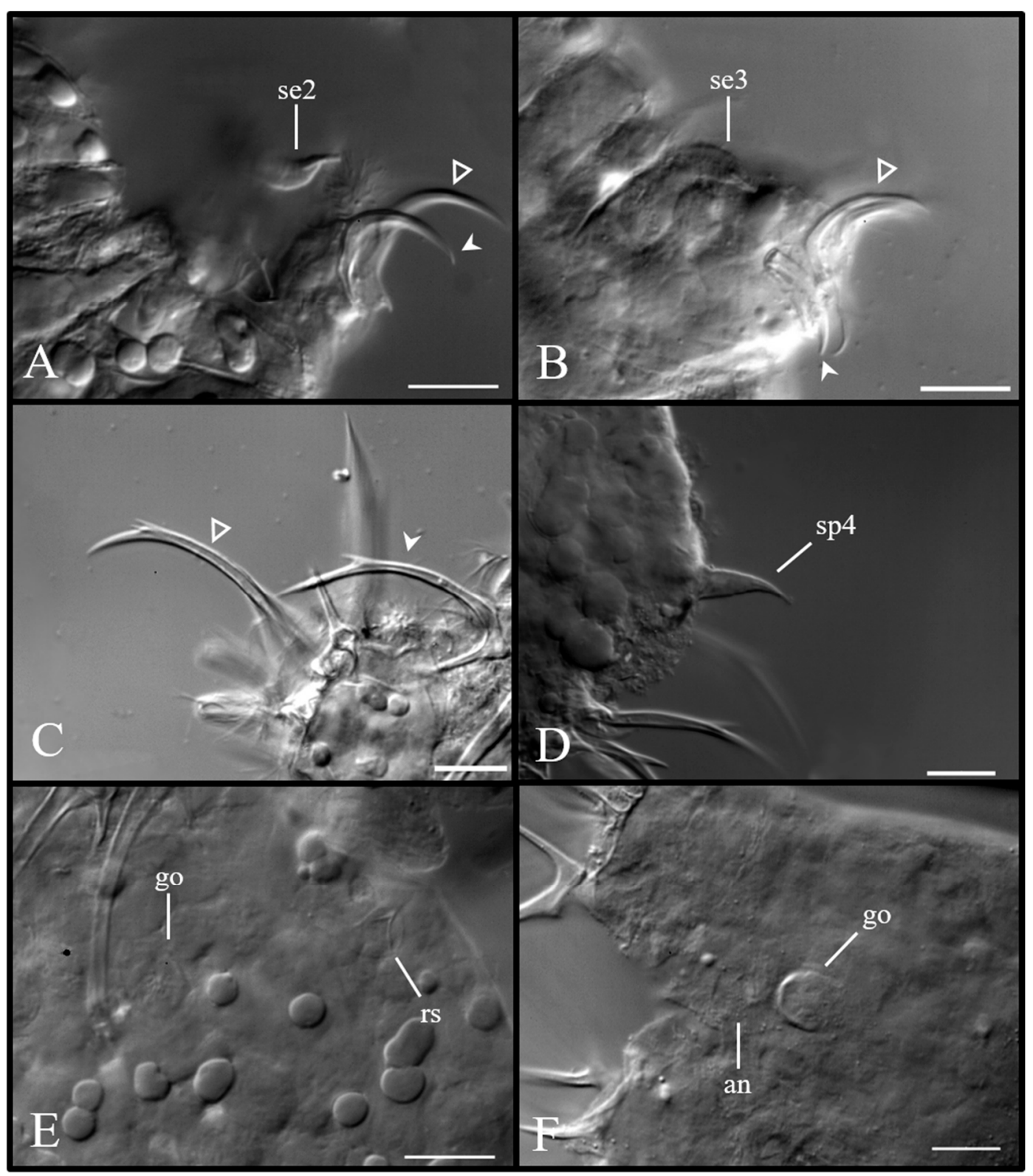

Figure 8. Coronarctus neptunus sp. nov. (A) Leg II, showing the sensory organ and the most external (indented arrowhead) and internal claws (empty arrowhead); (B) Leg III, showing the sensory organ and the most external (indented arrowhead) and internal claws (empty arrowhead); (C) Claws on legs IV, showing the accessory spines on internal claw (empty arrowhead) and external claw (indented arrowhead); (D) Coxal process on legs IV; (E) Female gonopore and seminal receptacle; (F) Male gonopore and anus. Abbreviations: an-anus; go-gonopore; rs-seminal receptacle; se2-3—sensory organ legs II-III; sp4—coxal process on leg IV. Scale bars: $10 \mu \mathrm{m}$. 
The mouth is subterminal and surrounded by cuticular folds. The spherical pharyngeal bulb is about $22 \mu \mathrm{m}$ in diameter. Other structures of the buccal apparatus (buccal tube, stylets, and placoids) were not observed.

The reproductive structures consist of a dorsal ovary and two pear-shaped seminal receptacles (each $12.1 \mu \mathrm{m}$ long) with straight duct directed backwards and curving anteriorly in the terminal portion only. Seminal ducts openings are located laterally at about $18 \mu \mathrm{m}$ from the rosette-like gonopore (Figures $6 \mathrm{~A}$ and $8 \mathrm{E}$ ). The anus, $14.5 \mu \mathrm{m}$ distant from the gonopore, is a short fissure surrounded by a wrinkled cuticle.

\subsubsection{Remarks}

The allotypic male does not display external sexual dimorphism, except for the gonopore that is a circular slit located at the top of a cylindrical cuticular fold, $7 \mu \mathrm{m}$ from the anus (Figure $8 \mathrm{~F}$ ). Two-clawed larvae were not found.

\subsubsection{Differential Diagnosis}

In Coronarctus neptunus sp. nov., secondary clavae do not display evident dorsal lobes and the edges jointed anteriorly, diverge backwards. Within the genus Coronarctus, this kind of dorsal-shaped secondary clavae is present in C. stylisetus only (see Figure 5). However, contrary to C. neptunus sp. nov., this species has long cephalic appendages and the claws display homomorphy (C. stylisetus group of species). In having short cephalic appendages and heteromorphic claws, the new species belongs to the C. tennellus group of species. In this group and similarly to C. neptunus sp. nov., only C. mexicus has annulated cephalic cirri and wrinkled leg sensory organs. In addition to the very differently shaped secondary clavae (dorsal edges diverging backwards and two ventral lobes in the new species, whereas the two dorsal lobes are described as very closely jointed and three ventral lobes are present in C. mexicus, see Figure 5), the two species can be clearly distinguished by another relevant taxonomic character, the claws. In the new species, claws IV are less curved, with long and sharp basal spurs, twin accessory spines on internal claws and a robust spine mediodorsally located (all claws more curved and with single apical accessory spines in C. mexicus). Moreover, in C. mexicus claws on legs I-III are thick and external and internal claws are not equal in size (16 and $23 \mu \mathrm{m}$ respectively in the holotype, which has a $294 \mu \mathrm{m}$ long body, i.e., the external/internal claws ratio is about 0.70), while in C. neptunus sp. nov. the claws of the three first leg pairs are longer, much thinner and much more similar in length (external/internal claws ratio $>0.74, \mathrm{n}=5$; in the $216 \mu \mathrm{m}$ long holotype this ratio is 0.81). The two species also differ in the relative size of sensory organs and coxal spine-like processes on the hind legs that are equal in size in C. mexicus, while sensory organs are much smaller than coxal spine-like processes in C. neptunus sp. nov. The new species also differs from all the known species of the genus in having straight seminal ducts directed backwards and curving anteriorly in the terminal portion only. In the other Coronarctus species the seminal duct curves immediately after the seminal receptacle, pointing anteriorly in six species and posteriorly in C. stylisetus.

\subsection{Coronarctus yurupari sp. nov.}

Figures 9-11, Supplementary Table S4.

\subsubsection{Diagnosis}

Coronarctus species with reduced leaf-like cephalic cirri. Spherical, pedunculated primary clavae. Flattened and strongly punctated secondary clavae with posterior ventral and dorsal lobes closely jointed. Cuticle smooth. Sensory organs present on each pair of legs. Small spine-like process on legs IV. Heteromorphic claws: claws of legs IV much longer than claws of the first three pairs of legs. All claws (internal and external) with a short apical accessory spine. On claws of legs IV an additional spine is present mediodorsally. 


\subsubsection{Type Locality:}

Potiguar Basin, Rio Grande do Norte State, Brazil; specimens were collected in the Brazilian continental slope between 991 and $2159 \mathrm{~m}$ below sea level $\left(04^{\circ} 36^{\prime}-04^{\circ} 46^{\prime} \mathrm{S} ; 36^{\circ} 05^{\prime}-36^{\circ} 31^{\prime} \mathrm{W}\right)$. The sediment type is fine mud.

\subsubsection{Type Material and Type Repository}

Holotype, adult male (slide Tard-UFRPE-01-98), allotype, adult female (slide Tard-UFRPE-01-29), and 9 paratypes: a female, 6 males, and 2 two-clawed larvae. The holotype (slide Tard-UFRPE-01-98), allotype (slideTard-UFRPE-01-29) and 6 paratypes: 5 males (slides Tard-UFRPE-01-26, Tard-UFRPE-01-30, and Tard-UFRPE-01-99), and a two-clawed larva (TARD-UFRPE-01-100) are deposited in the Laboratório de Meiofauna, Departamento de Biologia, Universidade Federal Rural de Pernambuco, Brazil (collection of Clélia Rocha). Three paratypes, 2 males (slides C.XI-71 and C.XI-72) and a two-clawed larva (slide C.XI-71) are deposited in the Department of Biology, Faculty of Sciences, University of Porto, Portugal (collection of P. Fontoura).

\subsubsection{Etymology}

The specific epithet yurupari refers to Yurupari, a demon in the mythology of some South American indigenous communities (namely the Mawé), considered the lord of darkness. The specific epithet alludes to the dark ocean depths where the new species was found.

\subsubsection{Description of the Holotype}

Adult male with a cylindrical and elongated body is $485 \mu \mathrm{m}$ long and $107 \mu \mathrm{m}$ wide (Figures $9 \mathrm{~A}$ and 10A). The cuticle, with metameric folds, is smooth and transparent. Coelomocytes and other globular bodies (about $5.2 \mu \mathrm{m}$ in diameter) are present in the body cavity. The head is well-differentiated and narrower than the body, bearing short leaf-like cephalic cirri (Figures 9B,C and 10B). The anterior conical part of the head bears the external $(6.8 \mu \mathrm{m})$ and internal cirri $(6.0 \mu \mathrm{m})$, median cirrus $(4.7 \mu \mathrm{m})$ and the secondary clavae. The posterior cylindrical part of the head bears the primary clavae $(7.8 \mu \mathrm{m})$ and lateral cirri $A(5.0 \mu \mathrm{m})$ (Figure 9A-C).

The spherical, finely punctated primary clavae are pedunculated and inserted separately from the shorter lateral cirri $A$. A very small constriction is present on the top of primary clavae (Figures 10D and 11A). The secondary clavae are flattened and strongly punctated (Figures 9B,C and 10C). Secondary clavae with two dorsal and two ventral lobes each. The dorsal and ventral posterior lobes are closely jointed (Figure 10C,D). Posterior dorsal end ventral edges of secondary clavae with a poorly marked indentation. The median cirrus is inserted between the anterior and the posterior dorsal lobes at about equal distance from the mouth opening and the posterior edge of secondary clavae.

Trunk cirri $B(5.0 \mu \mathrm{m}), C(16.0 \mu \mathrm{m})$, and $E(25.0 \mu \mathrm{m})$ are present as typical of the genus. Each trunk cirrus consists of a very short cirrophore, accordion-like scapus, and flagellum, which is particularly short on cirrus $B$, tapering into a blunt tip.

Short spine-like sensory organs are present dorsally on all pairs of legs; very short on legs I $(3.4 \mu \mathrm{m})$ and with similar size on legs II and III (5.3 and $5.2 \mu \mathrm{m}$, respectively), and terminating in a blunt tip on legs IV $(5.7 \mu \mathrm{m})$ (Figure 11B, white arrowhead).

The legs, particularly the first three pairs, are short and retractile. The hind legs, slightly longer and slender, have a spine-like process $(8.4 \mu \mathrm{m})$ inserted on the coxa (Figure 11B, black arrowhead). Each leg has four claws. Claws display marked heteromorphy: on the fourth pair of legs, claws are much longer than claws on the first three pairs of legs (on legs IV external claws are 49.3 and 52.3 and internal claws are 63.5 and $67.2 \mu \mathrm{m}$ long, on legs I the only external claw measured is 27.2 and internal claws are 34.0 and $38.0 \mu \mathrm{m}$ long); on all legs internal claws are slightly longer than external claws (see Table S4 for measurements, Figures 9A,D, 10A,D and 11C). The claws are curved, supplied with basal spurs and are connected to the leg by a membrane. All claws have an apical accessory spine 
(Figures 9D and 11C). Claws IV have an additional minute spine, located mediodorsally, very difficult to see (Figure 9D).

The mouth opening is terminal and surrounded by cuticular folds. The buccal tube is $70.0 \mu \mathrm{m}$ long, ending into large droplet-shaped apophyses (well visible in a paratype, Figure 11D). The oval pharyngeal bulb $(33.0 \mu \mathrm{m}$ long and $27.0 \mu \mathrm{m}$ wide) is devoided from placoids. Stylet supports are not perceptible in the holotype, in a paratype (body $352 \mu \mathrm{m}$ long; buccal tube $69.0 \mu \mathrm{m}$ ) the stylets (Figure 11D), without stylet supports, are $61.0 \mu \mathrm{m}$ long, ending into elongated bulbous furcae.

The gonopore is a circular slit located at the top of a cylindrical cuticular fold, $9.0 \mu \mathrm{m}$ distant from the anus (Figure 11E). The anal fissure is surrounded by three lobes of wrinkled cuticle.

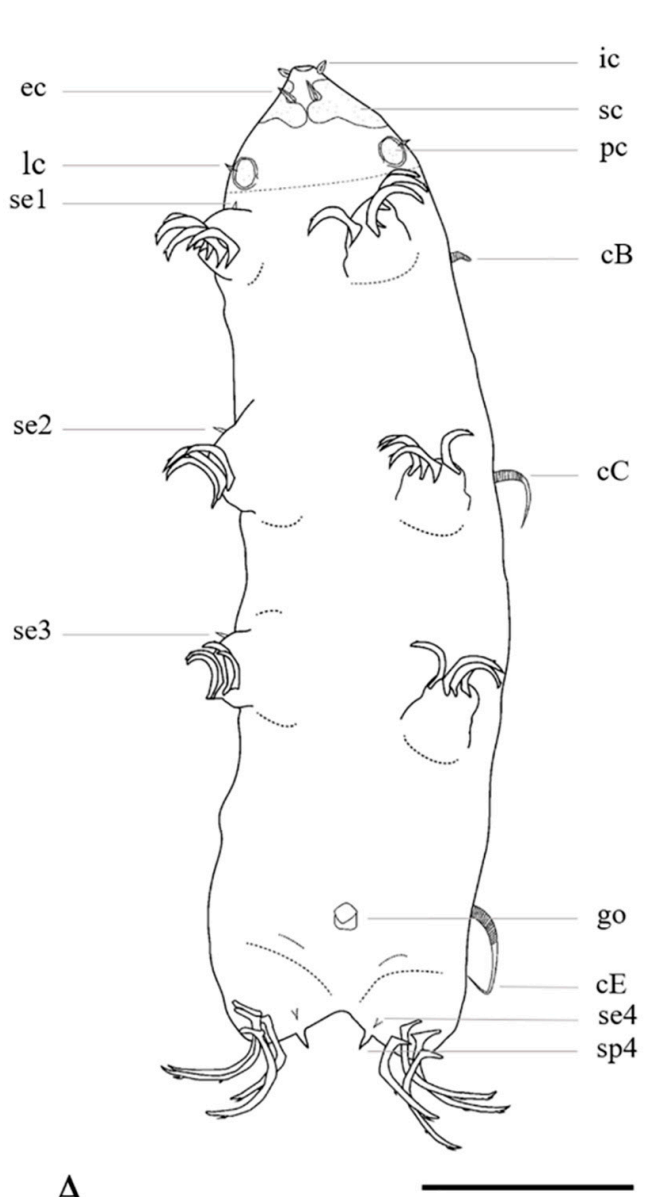

A
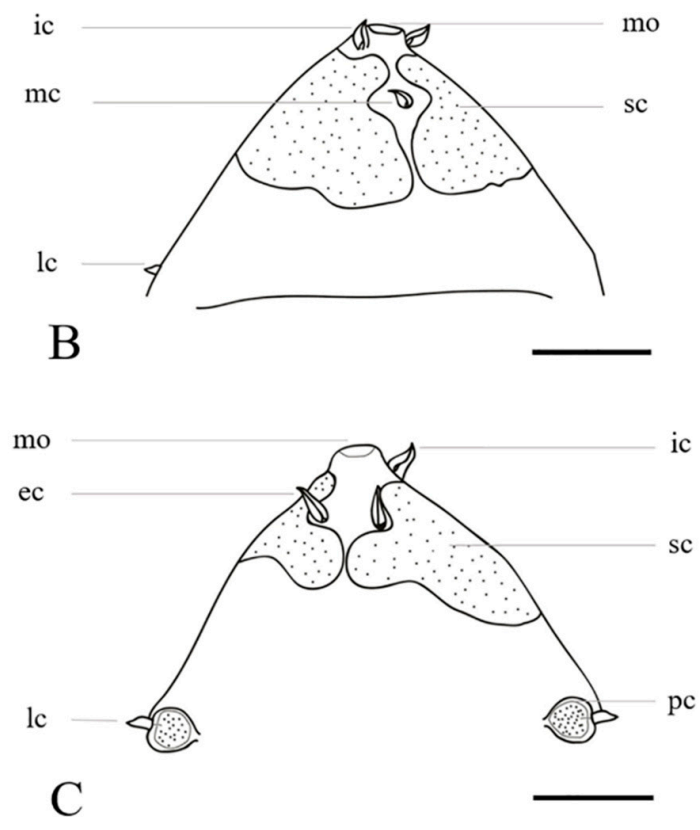

$\mathrm{C}$

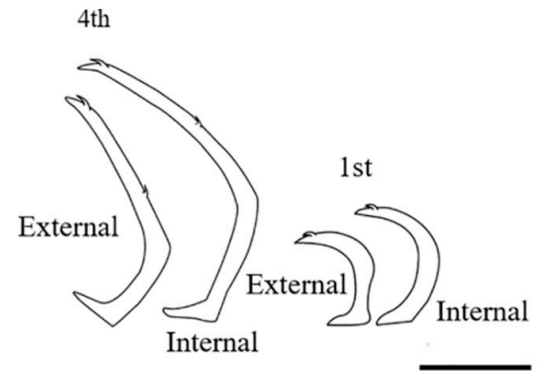

Figure 9. Coronarctus yurupari sp. nov. Drawings based on the holotype. (A) Ventral view of the body; (B) Dorsal view of the head; (C) Ventral view of the head; (D) Claws of the first and fourth pairs of legs. Abbreviations: $\mathrm{cB}$ - cirrus $B$; $\mathrm{CC}$ - cirrus $C$; $\mathrm{CE}$-cirrus $E$; ec-external cirrus; go-gonopore; ic—internal cirrus; lc-lateral cirrus $A$; mc - median cirrus; mo-mouth; pc—primary clava; sc—secondary clava; se1-4-sensory organ legs I-IV; sp4-coxal process on leg IV. Scale bars: A-50 $\mu \mathrm{m}, \mathrm{B}-\mathrm{D}-10 \mu \mathrm{m}$.

\subsubsection{Remarks}

Although only based on the examination of one female, except for her larger size, sexual dimorphism was not observed on external somatic structures. The female has two pear-shaped seminal receptacles, each consisting of a pouch $(11.0 \mu \mathrm{m}$ long $\times 9.0$ wide $\mu \mathrm{m})$ and a curving duct (about $33 \mu \mathrm{m}$ long) bending frontwards (Figure 11F). The duct opening is located at the same height as the rosette-like gonopore, which is $15.0 \mu \mathrm{m}$ distant from the anus. The ovary is seen dorsally. 
The claws on the two-clawed larvae, lacking gonopore and anus, all have a short apical spine. The additional spine located mediodorsally was not perceptible on claws IV. All the other characteristics are the same as the adult.

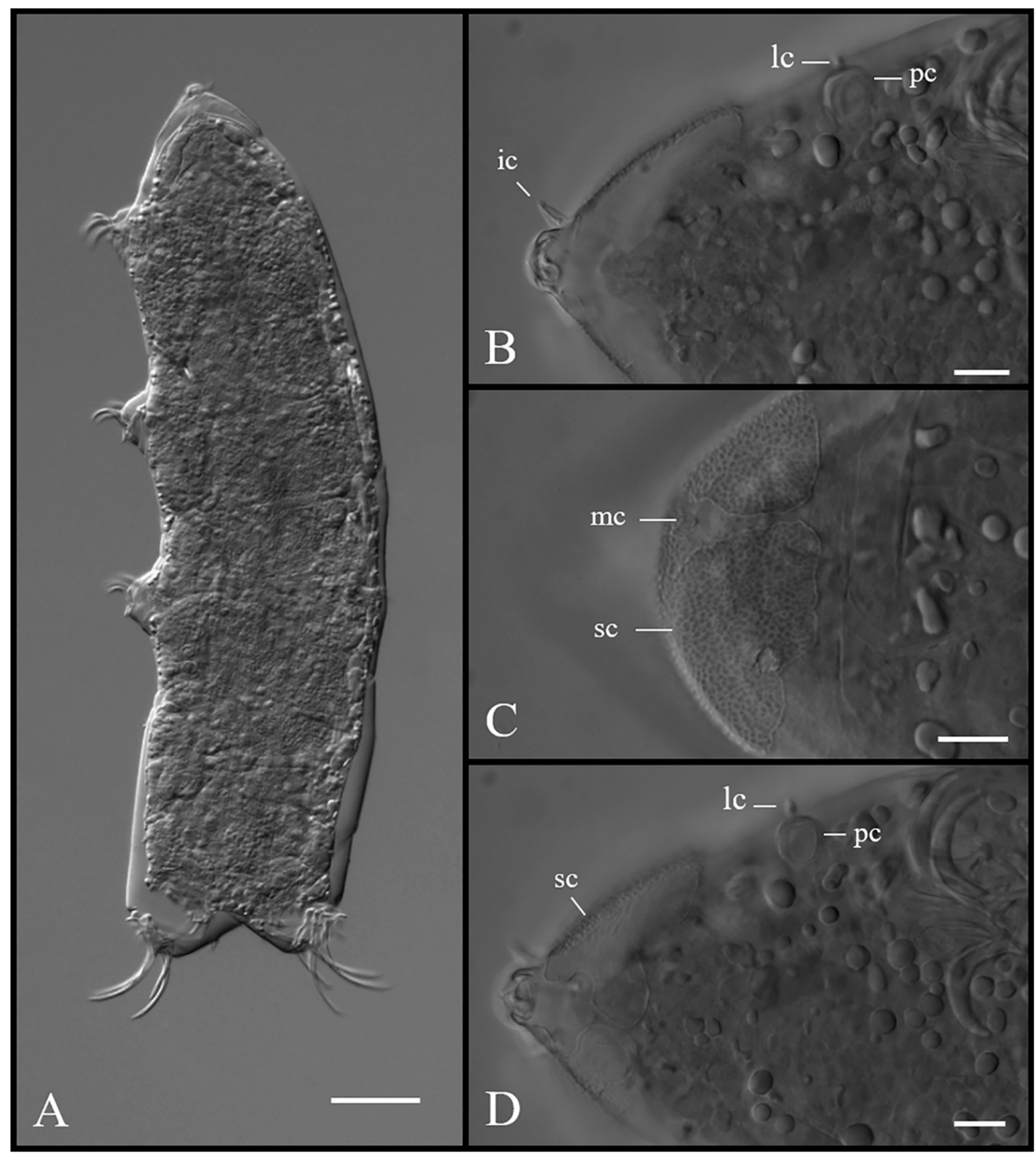

Figure 10. Coronarctus yurupari sp. nov. (A) Habitus; (B) Ventral view of the head showing the internal cirrus, primary clava, and lateral cirrus $A$; (C) Dorsal lobes of secondary clavae, notice the punctuation, and location of the median cirrus; (D) Ventral lobes of secondary clavae, primary clava, lateral cirrus $A$, and claws on legs I are also visible. Abbreviations: ic—internal cirrus; lc-lateral cirrus $A$; mc-median cirrus; pc—primary clava; sc—secondary clava. Scale bars: $10 \mu \mathrm{m}$. 


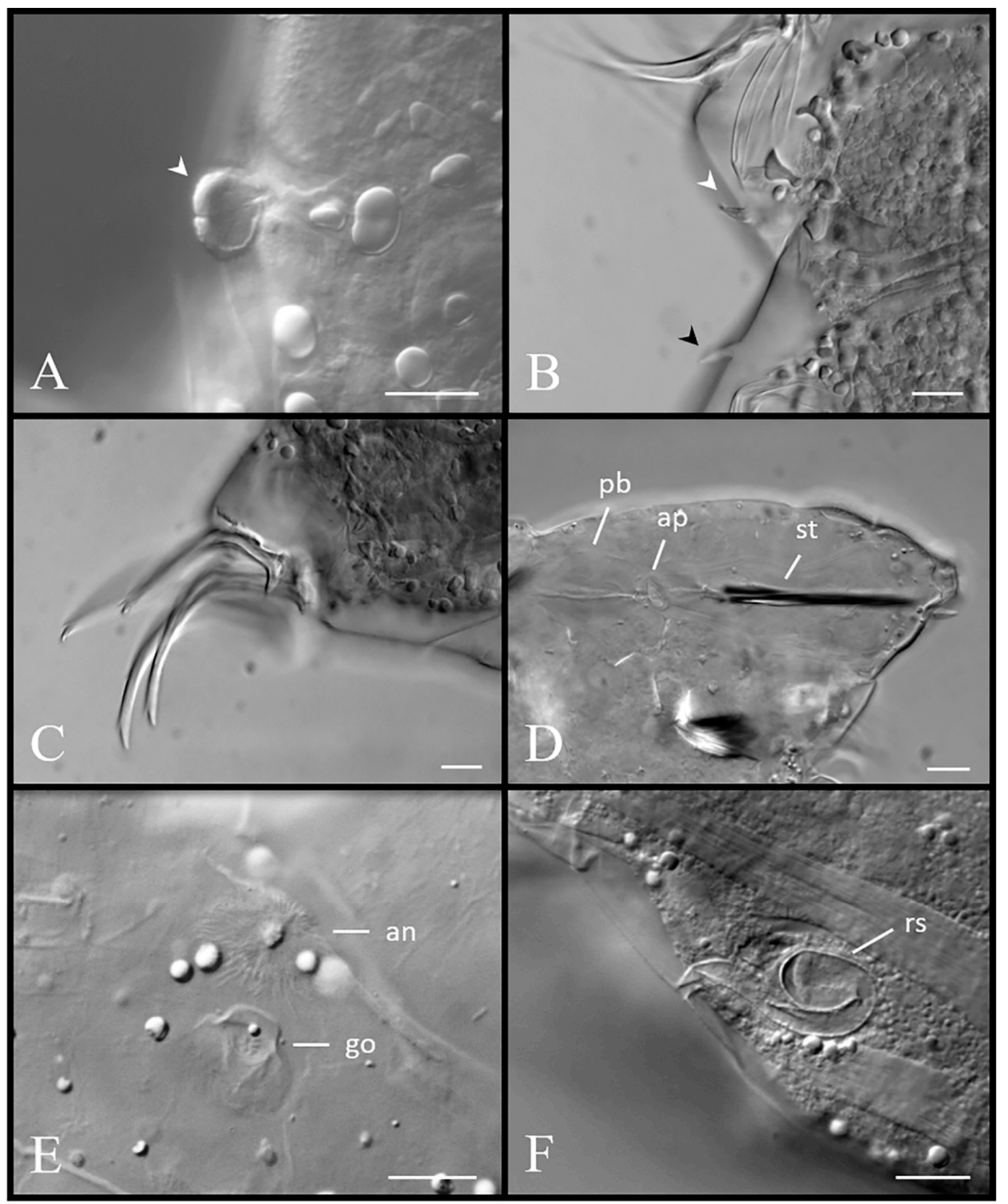

Figure 11. Coronarctus yurupari sp. nov. (A) Detail of the pedunculated primary clava, showing the distal indentation; (B) Sensory organ on leg IV (white arrowhead), the coxal process on legs IV is also visible (black arrowhead); (C) Claws on legs IV; (D) Buccal apparatus; (E) Male gonopore and anus; (F) Seminal receptacle of the allotypic female. Abbreviations: an-anus; ap-cuticular apophysis; go-gonopore; pb—pharyngeal bulb; rs—seminal receptacle; st—stylet. Scale bars: $10 \mu \mathrm{m}$.

\subsubsection{Differential Diagnosis}

As with the new species, belonging to the $C$. tennellus group of species, the other six described Coronarctus species also exhibit claw heteromorphy and have short cephalic appendages: C. tennellus, C. disparilis, C. laubieri, C. mexicus and the above newly described species C. dissimilis sp. nov. and C. neptunus sp. nov. Coronarctus yurupari sp. nov. has leaf-like cephalic cirri and the median cirrus inserted at equal distance from the posterior and anterior edges of secondary clavae and can be easily 
distinguished from C. laubieri and C. dissimilis (both with the median cirrus inserted posteriorly at the level of posterior edges of secondary clavae, see Figure 5) and from C. mexicus and C. neptunus sp. nov. (both species display cephalic cirri with accordion-like scapi). Moreover, C. yurupari sp. nov., differ from C. laubieri and C. dissimilis in lacking a deep indentation between the two ventral lobes of secondary clavae. The new species and C. mexicus exhibit different-shaped secondary clavae: two ventral lobes, from which the posterior lobe is jointed, are present in C. yurupari sp. nov., while three ventral lobes from which the posterior lobe is slightly separated are present in C. mexicus (see Figure 5). Coronarctus yurupari sp. nov. differs from the most similar species $C$. tenellus and $C$. disparillis by the claws, as follows:

- $\quad$ From C. tenellus, since C. yurupari has coxal spine-like processes on legs IV (absent in C. tenellus) and apical accessory spines on internal and external claws on all legs and additional mediodorsal spine on claws of legs IV (apical accessory spines on external claws and the additional spine are absent in C. tenellus);

- $\quad$ From C. disparilis, since C. yurupari has the additional spine on legs IV located mediodorsally, while in $C$. disparilis it is located on the ventral side of the claws. Apical accessory spines are present on all claws of legs I-III in the new species while lacking on external claws in C. disparilis. Moreover, the primary clavae are pedunculated in C. yurupari sp. nov. and subspherical in C. disparilis. The two species also differ in the shape of internal edges of the posterior lobes of secondary clavae that are circular in the new species and squarish in C. disparilis (Figure 5).

\section{Discussion}

Following this study, the number of Coronarctus species increases to ten. This diversity within the genus is supported by the specific variability of some relevant taxonomic morphological characters, such as the shape and development of cephalic cirri; the shape of secondary clavae; the claws, namely the size and number of accessory spines, and the shape of seminal receptacles, as recognized in previous studies, not only for the general taxonomy of marine tardigrades (for a review see [2,29]), but also for the particular case of Coronarctus [20,22,24,27].

The separation of Coronarctus species in two main groups, according to the size of cephalic appendages and relative size of claws on legs I-III and claws IV, was introduced by Renaud-Mornant [20], who provided the description of $C$. stylisetus and C. fastigatus, both species with long cephalic cirri and homomorphic claws, which were considered plesiomorphic characters. Renaud-Mornant [20], hypothesized that the reduction of cephalic cirri and claw heteromorphy observed in the other three Coronarctus species known at that time (C. tenellus, $C$. disparilis, and C. laubieri), could represent an apomorphic condition related to the adaptation to abyssal depths. This hypothesis was supported by Hansen [22], with the description of C. verrucatus, the third species with long cephalic cirri and claw homomorphy. Thus, according to these authors, C. stylisetus, C. fastigatus, (despite also being recorded at abyssal depths), and C. verrucatus belong to an evolutionary line, showing a tendency of bathyal distribution (recorded from depths comprised between 40-439 m; 675-2400 m, and 249-260 m, respectively, including the record of $C$. stylisetus from the Pacific Ocean by Noda [25]). By contrast C. tenellus, C. disparilis, and C. laubieri, from another evolutionary line, show a tendency towards an abyssal distribution (recorded from 1630-4690 m; $3400 \mathrm{~m}$, and 3600-4190 m, respectively). However, in addition to $C$. fastigatus, other species also overlap bathyal and abyssal depths in their bathymetric distribution. This is the case of C. mexicus, the last described species within the genus by Romano III et al. [24] before this study, which was recorded from 625-3250 $\mathrm{m}$ in depth, C. disparilis (763-3000 $\mathrm{m}$ ) and C. laubieri (625-3250 m), all from the Gulf of Mexico and all with short cephalic appendages [24]. In this study, taking into account their short cephalic appendages and heteromorphic claws, all species should have shown a tendency towards an abyssal distribution. This was the case of C. laubieri (collected from 1985-3000 m), C. dissimilis sp. nov. (1300 m) and C. yurupari sp. nov. (991-2159 m). On the contrary, the distribution of depth of $C$. neptunus sp. nov., ranging from 150 to $1300 \mathrm{~m}$ deep, shows that the species, although found in considerably deep waters, can colonize shallower zones too. In our 
opinion, the records of $C$. fastigatus from abyssal depths and $C$. disparilis, $C$. laubieri (considering that identifications of these two species in the Gulf of Mexico were correct), C. mexicus and C. neptunus sp. nov from bathyal depths, do not mean that the aforementioned hypothesis should be rejected, but that other unknown factors can influence the distribution of Coronarctus species in ocean depths. In order to facilitate the terminology to be used in future research, in this study the two evolutionary lines are named according to the first described species on each line: the $C$. tenellus group of species (with short cephalic appendages and heteromorphic claws) and the $C$. stylisetus group of species (with long cephalic cirri and homomorphic claws).

Which homomorphic and heteromorphic claws are displayed by each of the species of the genus that justify its assignment to one or the other of the evolutionary lineages mentioned above is a question that also needs clarification. As such, claws on legs I-III are compared with claws on legs IV and, if they are similar in size, a species is considered as displaying homomorphic claws. On the contrary, if claws on legs I-III are smaller than claws on legs IV, the species is considered as displaying heteromorphy. This should not be confused with different claw size exhibited between claws on the same leg. With the exception of C. laubieri, which displays much smaller external claws on legs IV than the internal claws, the two internal claws are about the same size or slightly longer than the two external claws for all the other species. Such kind of claw arrangement patterns, together with other aspects of claws, such as the number and size of accessory spines on each claw, express interspecific variability and are, consequently, very relevant for distinguishing species. It must be stressed, that accessory spines were not observed in the specimens identified as C. laubieri collected in this study from the South-Western Atlantic. Although all other characteristics perfectly match the description of this species, the eventual occurrence of cryptic speciation in this genus cannot be neglected as it also occurs in other marine tardigrade genera [31-34]. We presume that, with molecular data, this problem will be solved in the near future.

Novelties in the shape of secondary clavae on Coronarctus were also found in this study, confirming that interspecific variability can be translated by the number, size, and shape of dorsal and ventral lobes and punctuation, recommending a careful observation of this character in future identifications and species descriptions. The different shape patterns of secondary clavae displayed by all species are represented in Figure 5. Four main types can be recognized: (1) Two dorsal and two ventral lobes and posterior lobes jointing posteriorly (C. tenellus, C. disparillis, and C. yurupari sp. nov.); (2) Two dorsal lobes and two ventral lobes, the posterior ventral lobes separated from the anterior lobes by a deep indentation (in C. dissimilis sp. nov. and C. laubieri the median cirrus is inserted at the rear of the head); (3) Dorsal lobes poorly marked or absent, with dorsal edges of secondary clavae diverging posteriorly (C. fastigatus, also with divergent ventral lobes, C. neptunus sp. nov., C. stylisetus, and C. verrucatus, species with jointed posterior ventral lobes); (4) Three ventral lobes (C. mexicus, in the original description of this species the presence of two very close dorsal lobes is indicated but not illustrated). On the other hand, secondary clavae are described as strongly punctated in C. mexicus, C. verrucatus and C. yurupari. However, this character was not clearly described by Renaud-Mornat $[20,26,27]$, who referred to the presence of slightly punctated secondary clavae in C. tenellus. However, despite the subjectivity of the terminology used, in our opinion it was illustrated as strongly punctated $[26,27]$. Coronarctus disparillis and C. fastigatus were described as having thicker (without mention of punctuation) secondary clavae [20]. Therefore, it cannot be assumed that all the other species have smooth or finely punctated secondary clavae and this character needs to be confirmed.

The importance of female genital structures, namely the morphology of seminal receptacles as relevant taxonomic characters was highlighted for other tardigrade genera such as the Stygarctidae [35] and Archechiniscidae [36]. The reduction of seminal duct length in Coronarctus was previously referred to by Renaud-Mornant [20] as an apomorphic character. This author also noted that $C$. stylisetus was the only species within the genus with seminal ducts leaving the seminal receptacles by the anterior margin, curving immediately in a backwards direction. On the contrary, in all the other species the seminal 
ducts leave the seminal receptacles by the posterior margin and immediately loop in a frontward direction. In this study, the interspecific variability of the morphology of seminal ducts is increased with the discovery of a new pattern in C. neptunus sp. nov. In this species, the seminal ducts leave the seminal receptacles by the posterior margin and, without curving, direct backwards to the gonopore (a short curve directing the duct frontwards occurs near the seminal opening only).

Based on the description of the three new species that brought new insights to the taxonomy of the genus, as discussed above, a dichotomous key to the identification of all Coronarctus species is provided in this paper. It is also expected that these new insights could be pivotal to our understanding of the phylogeny of the genus.

As further concluding remarks, it is important to note that these are the first records of abyssal tardigrades from the South-Western Atlantic Ocean, contributing to the enhancement of our knowledge about the distribution and biogeography of the genus, confirming the uniqueness of this area and supporting the need for more extensive and deeper surveys.

\section{A Dichotomous Key for the Identification of Coronarctus Species}

$1 \mathrm{a}-$ Long cephalic cirri (internal and external cephalic cirri $>10 \mu \mathrm{m}$ long). Claws displaying homomorphy: claws on legs I-III and claws IV similar in length (C. stylisetus group of species) .........

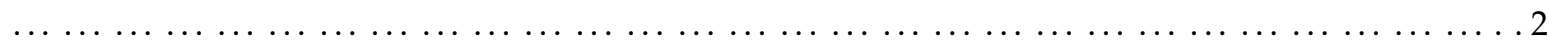
$1 \mathrm{~b}-$ Reduced cephalic cirri (internal and external cephalic cirri $<10 \mu \mathrm{m}$ long). Claws displaying heteromorphy: claws on legs IV much longer than claws on legs I-III (C. tenellus group of species) ...

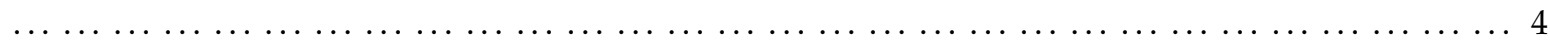

$2 \mathrm{a}$ - Cuticle smooth. Pedunculated, with or without a pedestalate socket, primary clava. Secondary clava with ventral lobes not posteriorly indented $\ldots \ldots \ldots \ldots \ldots \ldots \ldots \ldots \ldots \ldots \ldots$ $2 \mathrm{~b}$ - Cuticle studded with numerous small wart-like excrescences. Primary clava with a large base, not pedunculated. Secondary clavae with closely jointed posterior ventral lobes that have a posterior narrowing indentation (Figure 5$) \ldots \ldots \ldots \ldots \ldots \ldots \ldots \ldots \ldots \ldots \ldots \ldots \ldots \ldots \ldots \ldots$. verrucatus Hansen, 2007 $3 a-S e c o n d a r y ~ c l a v a$ with posterior ventral lobes jointed (Figure 5). Females with seminal ducts directed posteriorly to the gonopore ......................... . stylisetus Renaud-Mornant, 1987 $3 \mathrm{~b}-$ Secondary clava with posterior ventral lobes widely separated (Figure 5). Females with seminal ducts ascending anteriorly $\ldots \ldots \ldots \ldots \ldots \ldots \ldots \ldots \ldots \ldots \ldots \ldots \ldots \ldots$. fastigatus Renaud-Mornant, 1987 $4 \mathrm{a}$ - Median cephalic cirrus inserted posteriorly at the level of posterior edges of secondary clavae. Narrow and elongated posterior ventral lobes of secondary clavae separated from the anterior lobes by

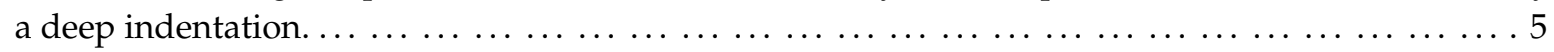
$4 \mathrm{~b}$ - Median cephalic cirrus inserted at about equal distance from the posterior and anterior edges of secondary clavae. Broad and short posterior ventral lobes of secondary clavae $\ldots \ldots \ldots \ldots \ldots \ldots 6$ $5 a-$ Claws of hind legs displaying marked heteromorphy, i.e., internal claws are much longer than external claws (external/external claws $\leq 0.50$ ). Posterior dorsal lobes of secondary clavae converging to the midsagittal line (Figure 5). Claws of legs IV with accessory spines on internal claws and simple external claws. .................................... laubieri Renaud-Mornant, 1987 $5 \mathrm{~b}$-Claws of hind legs with poorly marked heteromorphyy, i.e., internal claws just slightly longer than external claws (external/external claws $\geq 0.70$ ). Posterior dorsal lobes of secondary clavae diverging from the midsagittal line (Figure 5). All claws of legs IV with dorsal accessory spines............

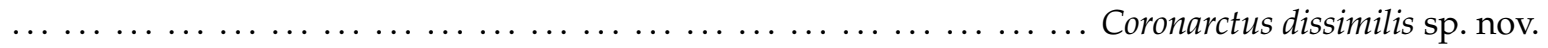
$6 a-$ Leaf-like or stylet-like cephalic appendages, without annulated scapi; leg sensory organs smooth.

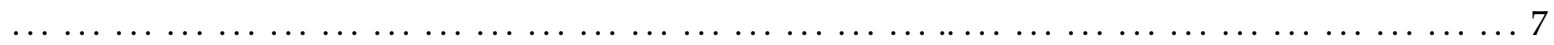
$6 b-C e p h a l i c$ appendages with annulated scapi and short terminal tube; wrinkled leg sensory organs.

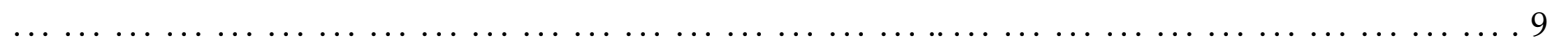
7a - Posterior ventral lobes of secondary clavae, although converging to the midsagittal line not closely jointed (Figure 5). Coxal processes on legs IV absent. Internal claws IV with accessory spines, and external claws simple................................ tenellus Renaud-Mornant, 1974 
$7 \mathrm{~b}-$ Posterior ventral lobes of secondary clavae closely jointed. Coxal processes on legs IV present. All claws on legs IV with apical accessory spines and, at least on internal claws, an additional spine is

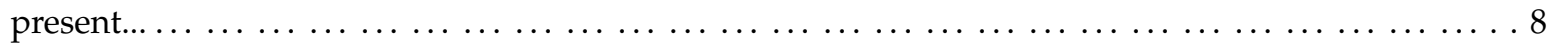
$8 \mathrm{a}$ - Posterior ventral lobes of secondary clavae very wide and with a straight edge in the midsagittal line (Figure 5). On hind legs, all claws with apical accessory spines; a conspicuous supplementary spine is present on internal claws IV only (located on the ventral side of claws). Internal claws of the first three pairs of legs with accessory spines, external claws simple (a minute bulge can be present)....

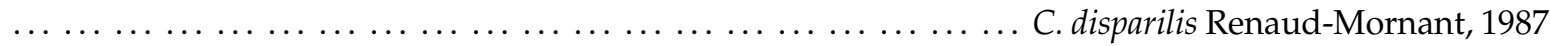
$8 \mathrm{~b}$ - Posterior ventral lobes of secondary clavae with a curved edge in the midsagittal line (Figure 5). On hind legs, minute supplementary spines are present on all claws (located on the dorsal side of claws). All claws on the first three pairs of legs with accessory spines ... Coronarctus yurupari sp. nov. 9a-Secondary clavae with two very close dorsal lobes and three ventral lobes (Figure 5). All claws with apical accessory spines. Similar sized sensory organs and coxal processes on legs IV ........... ... ............... C. mexicus Romano III, Gallo, D'Addabbo, Accogli, Baguley \& Montagna, 2011 $9 \mathrm{~b}$ - Secondary clavae not displaying dorsal lobes with the mid-dorsal edges diverging posteriorly from the midsagittal line and having two ventral lobes (Figure 5). On legs IV apical accessory spines present on internal claws; external claws with a well-developed spine located mediodorsally. Sensory organs on legs IV smaller than coxal processes................ Coronarctus neptunus sp. nov.

Supplementary Materials: The following are available online at http://www.mdpi.com/1424-2818/12/2/63/s1, Table S1: Measurements (in $\mu \mathrm{m}$ ) of selected morphological structures of the holotype, allotype and paratypes of Coronarctus dissimilis sp. nov., Table S2: Measurements (in $\mu \mathrm{m}$ ) of selected morphological structures of Coronarctus laubieri Renaud-Mornant, 1987 from Brazil, Table S3: Measurements (in $\mu \mathrm{m}$ ) of selected morphological structures of the holotype, allotype and paratypes of Coronarctus neptunus sp. nov. Table S4: Measurements (in $\mu \mathrm{m}$ ) of selected morphological structures of the holotype, allotype, and paratypes of Coronarctus yurupari sp. nov., Figure S1: Photos of the habitus and some structures of specimens of Coronarctus laubieri Renaud-Mornant, 1987 from Brazil, Figure S2: Drawings of the habitus and some structures of specimens of Coronarctus laubieri Renaud-Mornant, 1987 from Brazil.

Author Contributions: Conceptualization, E.G.-J. and P.F.; methodology, C.M.C.d.R., E.G.-J., É.S. and P.F.; validation, E.G.-J. and P.F.; formal analysis, E.G.-J., É.S., and P.F.; investigation, C.M.C.d.R., E.G.-J., É.S., and P.F.; resources, C.M.C.d.R., P.F. and P.J.P.S.; data curation, C.M.C.d.R., and P.F.; writing-original draft preparation, E.G.-J., É.S., and P.F.; writing-review and editing, E.G.-J., É.S., C.M.C.d.R., P.F. and P.J.P.S., supervision, P.F. and P.J.P.S.; project administration, E.G.-J.; funding acquisition, P.F. and P.J.P.S. All authors have read and agreed to the published version of the manuscript.

Funding: During this study, Edivaldo L. Gomes-Júnior was supported by a doctoral grant (IBPG-0648-2.04/15) awarded by FACEPE (Fundação de Amparo à Ciência e Tecnologia do Estado de Pernambuco). Paulo Santos was partially funded by Conselho Nacional de Desenvolvimento Científico e Tecnológico (CNPq 306444/2014-3). The research of P. Fontoura (Portugal) was partially funded by Fundação para a Ciência e Tecnologia (FCT) through the strategic project UID/MAR/04292/2019 granted to MARE.

Acknowledgments: The authors are grateful to Petrobras S/A (Brazil) for providing the deep-sea samples used in this research. Special thanks are due to Rebecca N. Umeed for assistance with English language. The authors are also grateful to three anonymous reviewers for their helpful comments that improved this paper.

Conflicts of Interest: The authors declare no conflict of interest.

\section{References}

1. Kristensen, R.M.; Hansen, J.G. Tardigrada (water bears). In Marine Parasitology; Rhode, K., Ed.; CSIRO publishing: Clayton, Australia, 2005; pp. 230-235.

2. Fontoura, P.; Bartels, P.J.; Jørgensen, A.; Kristensen, R.M.; Hansen, J.G. A dichotomous key to the genera of the Marine Heterotardigrades (Tardigrada). Zootaxa 2017, 4294, 1-45. [CrossRef]

3. Nelson, D.R.; Bartels, P.J.; Guil, N. Tardigrade Ecology. In Water Bears: The Biology of Tardigrades; Schill, R.O., Ed.; Zoological Monographs 2; Springer Nature Switzerland AG: Cham, Switzerland, 2018; Chapter 7; pp. 163-210. [CrossRef]

4. Kaczmarek, Ł.; Bartels, P.J.; Roszkowska, M.; Nelson, D.R. The Zoogeography of Marine Tardigrada. Zootaxa 2015, 4037, 1-189. [CrossRef] 
5. Degma, P.; Guidetti, R. Tardigrade Taxa. In Water Bears: The Biology of Tardigrades; Schill, R.O., Ed.; Zoological Monographs 2; Springer Nature Switzerland AG: Cham, Switzerland, 2018; Chapter 15; pp. 371-409. [CrossRef]

6. Actual checklist of Tardigrada species (36th Edition: 1-09-2019). 2009-2019. Available online: https: //iris.unimore.it/handle/11380/1178608\#.XIXnUHERXIU (accessed on 12 September 2019).

7. Bartels, P.J.; Apodaca, J.J.; Mora, C.; Nelson, D.R. A global biodiversity estimate of a poorly known taxon: Phylum Tardigrada. Zool. J. Linn. Soc. 2016, 178, 730-736. [CrossRef]

8. Thiel, H. Quantitative Untersuchungen über die Meiofauna des Tiefseebodens. Veröffentlichungen des Instituts für Meeresforschung in Bremerhaven 1966, 2, 131-148.

9. Kristensen, R.M.; Sørensen, M.V.; Hansen, J.G.; Zeppilli, D. A new species of Neostygarctus (Arthrotardigrada) from the Condor Seamount in the Azores, Northeast Atlantic. Mar. Biodivers. 2015, 45, 453-467. [CrossRef]

10. Tchesunov, A.V. A new tardigrade species of the genus Neostygarctus Grimaldi de Zio et al., 1982 (Tardigrada, Arthrotardigrada) from the Great Meteor Seamount, Northeast Atlantic. Eur. J. Taxon. 2018, 479, 1-17. [CrossRef]

11. Fujimoto, S.; Hansen, J.G. Revision of Angursa (Arthrotardigrada: Styraconyxidae) with the description of a new species from Japan. Eur. J. Taxon. 2019, 510, 1-19. [CrossRef]

12. Renaud-Mornant, J. Deux nouveaux Angursa Pollock, 1979, du domaine abyssal (Tardigrada, Arthrotardigrada). Tethys 1981, 10, 161-164.

13. Da Rocha, C.M.C.; Santos, E.C.L.; Gomes, E.L., Jr.; Moura, J.R.; Silva, L.G.S.; Barbosa, D.F. New records of marine tardigrades from Brazil. J. Limnol. 2013, 72, 102-107. [CrossRef]

14. Menechella, A.G.; Bulnes, V.N.; Cazzaniga, N.J. Two new species of Batillipes (Tardigrada, Arthrotardigrada, Batillipedidae) from the Argentinean Atlantic coast, and key to all known species. Mar. Biodivers. 2018, 48, 239-247. [CrossRef]

15. Santos, E.; da Rocha, C.M.C.; Gomes, E., Jr.; Fontoura, P. Three new Batillipes species (Arthrotardigrada: Batillipedidae) from the Brazilian coast. Zootaxa 2017, 4243, 483-502. [CrossRef] [PubMed]

16. Gomes, E., Jr.; Santos, E.; da Rocha, C.M.C.; Santos, P.J.P.; Fontoura, P. A new species of Ligiarctus (Tardigrada, Heterotardigrada) from the Brazilian continental shelf, Southwestern Atlantic Ocean. Mar. Biodivers. 2018, 48, 5-12. [CrossRef]

17. Zeppilli, D.; Sarrazin, J.; Leduc, D.; Martinéz-Arbizu, P.; Fontaneto, D.; Fontanier, C.; Gooday, A.J.; Kristensen, R.M.; Ivanenko, V.N.; Sørensen, M.V.; et al. Is the meiofauna a good indicator for climate change and anthropogenic impacts? Mar. Biodivers. 2015, 45, 505-535. [CrossRef]

18. Zeppilli, D.; Leduc, D.; Fontanier, C.; Fontaneto, D.; Fuchs, S.; Gooday, A.J.; Goineau, A.; Ingels, J.; Ivanenko, V.N.; Kristensen, R.M.; et al. Characteristics of meiofauna in extreme marine ecosystems: A review. Mar. Biodivers. 2018, 48, 35-71. [CrossRef]

19. Vanreusel, A.; Hilario, A.; Ribeiro, P.A.; Menot, L.; Arbizu, P.M. Threatened by mining, polymetallic nodules are required to preserve abyssal epifauna. Sci. Rep. 2016, 6, 26808. [CrossRef]

20. Renaud-Mornant, J. Bathyal and abyssal Coronarctidae (Tardigrada), description of new species and phylogenetical significance. In Biology of Tardigrades. Selected Symposia and Monographs U.Z.I; Bertolani, R., Ed.; 1. Mucchi Editore: Modena, Italy, 1987; pp. 229-252.

21. Hansen, J.G.; Jørgensen, A.; Kristensen, R.M. Preliminary studies of the tardigrade fauna of the Faroe Bank. Zool. Anz. 2001, 240, 385-393. [CrossRef]

22. Hansen, J.G. The deep sea elements of the Faroe Bank tardigrade fauna with a description of two new species. J. Limnol. 2007, 66, 12-20. [CrossRef]

23. Rubal, M.; Fontoura, P.; Veiga, P. Effects of sediment organic enrichment on a high diversity tardigrade assemblage in the Ría de Muros (NW Spain). In Book of Abstracts, Proceedings of the SeventIMCO - Seventeenth International Meiofauna Conference, Évora, Portugal, 7-12 July 2019; Adão, H., Vicente, C., Sroczyńska, K., Espada, M., Alvim, P., Costa, M., Vieira, S., Eds.; Abstract 5999, Special Publication; University of Évora: Évora, Portugal, 2019; ISBN 978-989-8550-97-2.

24. Romano, F., III; Gallo, M.; D’Addabbo, R.; Accogli, G.; Bagueley, J.; Montagna, P. Deep-sea tardigrades in the northern Gulf of Mexico with a description of a new species of Coronarctidae (Tardigrada: Arthrotardigrada), Coronarctus mexicus. J. Zool. Syst. Evol. Res. 2011, 49, 48-52. [CrossRef]

25. Noda, H. The first occurrence of coronarctid tardigrade from the shallow water. Zool. Sci. 1989, 6, 1220. 
26. Renaud-Mornant, J. Une nouvelle famille de Tardigrades marins abyssaux: Coronarctidae fam. nov. (Heterotardigrada). C. R. Acad. Sci. 1974, 278, 3087-3090.

27. Renaud-Mornant, J. Deep Sea Tardigrada from “Meteor" Indian Ocean Expedition. "Meteor" Forsh.-Ergebnisse 1975, 21, 54-61.

28. Fujimoto, S.; Jørgensen, A.; Hansen, J.G. A molecular approach to arthrotardigrade phylogeny (Heterotardigrada, Tardigrada). Zool Scr. 2017, 46, 496-505. [CrossRef]

29. Møbjerg, N.; Jørgensen, A.; Kristensen, R.M.; Neves, R.C. Morphology and Functional Anatomy. In Water Bears: The Biology of Tardigrades; Schill, R.O., Ed.; Zoological Monographs 2; Springer Nature Switzerland AG: Cham, Switzerland, 2018; Chapter 2; pp. 57-94. [CrossRef]

30. Renaud-Mornant, J. Dévelopement postembryonnaire du Tardigrade abyssal Coronarctus laubieri Renaud-Mornant, 1987 (Tardigrada, Heterotardigrada). Bull. Mus. Natl. Hist. Nat. 1988, 10, 327-345.

31. Faurby, S.; Jørgensen, A.; Kristensen, R.M.; Funch, P. Phylogeography of North Atlantic intertidal tardigrades: Refugia, cryptic speciation and the history of the Mid-Atlantic Islands. J. Biogeogr. 2011, 38, 1613-1624. [CrossRef]

32. Faurby, S.; Jørgensen, A.; Kristensen, R.M.; Funch, P. Distribution and speciation in marine intertidal tardigrades: Testing the roles of climatic and geographical isolation. J. Biogeogr. 2012, 39, 1596-1607. [CrossRef]

33. Perry, E.S.; Rawson, P.; Ameral, N.J.; Miller, W.R.; Miller, J.D. Echiniscoides rugostellatus a new marine tardigrade from Washington U.S.A. (Heterotardigrada: Echiniscoidea: Echiniscoididae: Echiniscoidinae). Proc. Biol. Soc. Wash. 2018, 131, 182-193. [CrossRef]

34. Santos, E.; Veiga, P.; Rubal, M.; Bartels, P.J.; Da Rocha, C.M.C.; Fontoura, P. Batillipes pennaki Marcus, 1946 (Arthrotardigrada: Batillipedidae): Deciphering a species complex. Zootaxa 2019, 4648, 549-567. [CrossRef]

35. Hansen, J.G.; Kristensen, R.M.; Jørgensen, A. The armoured marine tardigrades (Arthrotardigrada, Tardigrada). Sci. Dan. 2012, 2, 1-91.

36. Bartels, P.J.; Fontoura, P.; Nelson, D.R. Marine tardigrades of the Bahamas with the description of two new species and updated keys to the species of Anisonyches and Archechiniscus. Zootaxa 2018, 4420, 43-70. [CrossRef]

(C) 2020 by the authors. Licensee MDPI, Basel, Switzerland. This article is an open access article distributed under the terms and conditions of the Creative Commons Attribution (CC BY) license (http://creativecommons.org/licenses/by/4.0/). 